\section{Zircon U-Pb Geochronology Links the End-Triassic Extinction with the Central Atlantic Magmatic Province}

\author{
Terrence ]. Blackburn, ${ }^{1 *} \dagger$ Paul E. Olsen, ${ }^{2}$ Samuel A. Bowring, ${ }^{1}$ Noah M. McLean, ${ }^{1}$ \\ Dennis V. Kent, ${ }^{2,3}$ John Puffer, ${ }^{4}$ Greg McHone, ${ }^{5}$ E. Troy Rasbury, ${ }^{6}$ Mohammed Et-Touhami ${ }^{7}$
}

The end-Triassic extinction is characterized by major losses in both terrestrial and marine diversity, setting the stage for dinosaurs to dominate Earth for the next 136 million years. Despite the approximate coincidence between this extinction and flood basalt volcanism, existing geochronologic dates have insufficient resolution to confirm eruptive rates required to induce major climate perturbations. Here, we present new zircon uranium-lead (U-Pb) geochronologic constraints on the age and duration of flood basalt volcanism within the Central Atlantic Magmatic Province. This chronology demonstrates synchroneity between the earliest volcanism and extinction, tests and corroborates the existing astrochronologic time scale, and shows that the release of magma and associated atmospheric flux occurred in four pulses over about 600,000 years, indicating expansive volcanism even as the biologic recovery was under way.

$\mathrm{T}$ he approximate temporal coincidence between the five major extinction events over the past 542 million years and the eruption of large igneous provinces (LIPs) has led to speculation that environmental perturbations generated by the emplacement of large volumes of magma and associated outgassing over short periods of time triggered each global biologic crisis (1). Establishing an exact link between extinctions and LIP eruptions has proved difficult because of the geographic separation between LIP volcanic deposits and stratigraphic sequences preserving evidence of the extinction. In most cases, uncertainties on radioisotopic dates used to correlate between geographically separated study areas exceed the duration of both the extinction interval and LIP volcanism by an order of magnitude. This hinders evaluation of any relationship between magmatism and extinction and precludes accurate estimates of volcanic effusion rates, associated volatile release, and extinction mechanisms.

The end-Triassic extinction (ETE) - marked within early Mesozoic basins of eastern North America by a dramatic turnover in fossil pollen, spores (sporomorphs), and vertebrates (2) - is one of the largest Phanerozoic mass extinctions,

${ }^{1}$ Department of Earth, Atmospheric and Planetary Sciences, Massachusetts Institute of Technology, Cambridge, MA 02139, USA. ${ }^{2}$ Lamont-Doherty Earth Observatory of Columbia University, Palisades, NY 10964, USA. ${ }^{3}$ Department of Earth and Planetary Sciences, Rutgers University, Piscataway, N] 08554, USA. ${ }^{4}$ Department of Earth and Environmental Sciences, Rutgers University, Newark College of Arts and Sciences, Newark, N] 07102, USA. 59 Dexters Lane, Grand Manan, New Brunswick E5G 1A1, Canada. ${ }^{6}$ Department of Geosciences, Stony Brook University, Stony Brook, NY 11794, USA. Département des Sciences de la Terre, Université Mohammed Premier Oujda, 60000 Oujda, Morocco. *Present address: Department of Terrestrial Magnetism, Carnegie Institution for Science, Washington, DC 20015, USA. †Corresponding author. E-mail: tblackburn@ciw.edu occurring just before the Triassic-Jurassic boundary $(3,4)$, and has long been thought to be associated with the eruptions of the Central Atlantic Magmatic Province (CAMP) (5, 6). CAMP is the most aerially extensive LIP on Earth, and with volume estimates between $2-3 \times 10^{6} \mathrm{~km}^{3}$, it ranks as one of the most voluminous (7) (Fig. 1). Remnants of CAMP are found on four continents and consist primarily of continental thoeliitic basalts emplaced as subaerial flows and intrusive bodies during rifting of the Pangean supercontinent and incipient formation of the Atlantic Ocean basin (Fig. 1). Estimates of the timing and duration of CAMP provided by astrochronology $(8,9)$ and ${ }^{40} \mathrm{Ar} /{ }^{39} \mathrm{Ar}$ geochronology $(10,11)$ differ by an order of magnitude, preventing high-precision tests of the relationship between LIP volcanism and mass extinction. Use of the astrochronologic time-scale, though potentially precise, relies on (i) recognition of the influence of orbital cycles in the rock record and (ii) the ability to predict orbital durations in the deep geologic past, both of which have engendered doubts about the reliability of the technique. The lower precision of ${ }^{40} \mathrm{Ar} /{ }^{39} \mathrm{Ar}$ dates (fig. S1) prevents estimation of the volume of magma erupted over unit time, a critical factor for evaluating extinction mechanisms such as $\mathrm{CO}_{2}$ induced global warming $(12,13)$ ocean acidification $(14,15)$, or sulfur aerosol-induced "volcanic winters" (16).

\section{U-Pb Geochronology of CAMP Flows and Intrusives}

Here, we present zircon $\left(\mathrm{ZrSiO}_{4}\right) \mathrm{U}-\mathrm{Pb}$ geochronologic data for CAMP magmatism from seven sites in eastern North America and one in Morocco (Fig. 1), integrated with paleobiological, geochemical, and paleomagnetic data derived from sedimentary sequences interbedded with and intruded by the magmatic rocks. These data provide (i) a precise determination of the onset and duration of CAMP magmatism and (ii) a test of the reliability of the astronomical time scale in order to provide a high-precision age model for the CAMP-ETE interval $(8,9)$. Though U-Pb dating of zircon permits an order of magnitude improvement over previous ${ }^{40} \mathrm{Ar}{ }^{39} \mathrm{Ar}$ studies (fig. $\mathrm{S} 1$ ), this preferred mineral for $\mathrm{U}-\mathrm{Pb}$ dating is uncommon in basaltic rocks. This forced our sample collection to focus on finding isolated coarsegrained segregations within gabbroic intrusions and thick subaerial flows where incompatible elementenriched residual melts resulted in the crystallization of zircon (17) (fig. S2). The reported zircon $\mathrm{U}-\mathrm{Pb}$ dates are ${ }^{238} \mathrm{U}_{-}^{206} \mathrm{~Pb}$ weighted mean dates with $\pm 2 \sigma$ analytical uncertainties corrected for initial ${ }^{230}$ Th disequilibrium (figs. S3 and S4) (18).

Stratigraphically constrained basalt flows, such as the North Mountain and Preakness basalts, provide the most straightforward means of directly

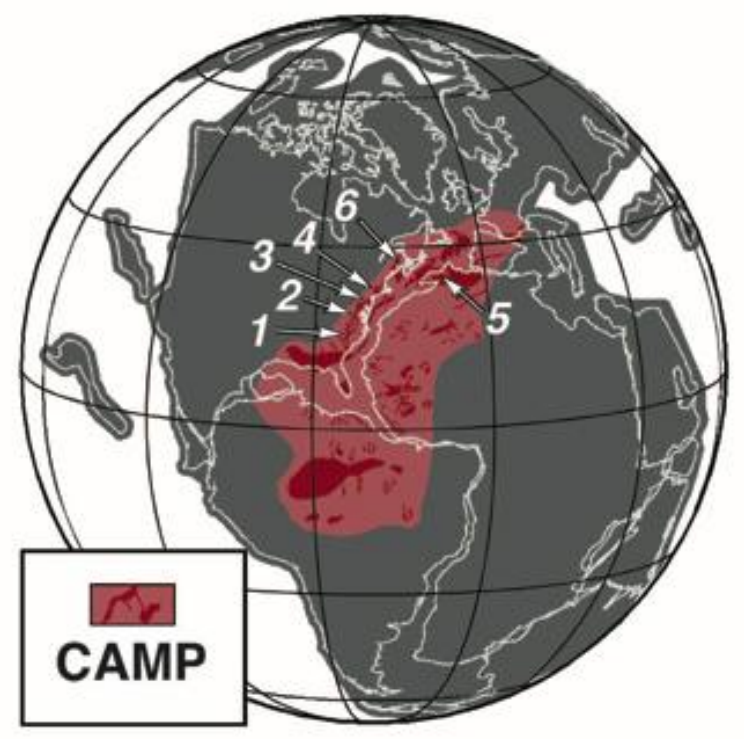

Fig. 1. Location and extent of CAMP magmatism within the Pangean supercontinent. Earliest Jurassic plate configuration showing distribution of the CAMP [based on $(36,40)]$, including the total areal distribution (pink) and preserved remnants of CAMP (dark red) [based on (5)], and the location of the studied basins: 1, Deep River, North Carolina, USA; 2, Culpeper, Virginia, USA; 3 , Gettysburg, Pennsylvania, USA; 4, Newark, New Jersey, USA; 5, Argana, Morocco; and 6, Fundy, Nova Scotia, Canada. 
dating the Triassic and Early Jurassic stratigraphy (Fig. 2). However, coarse-grained zircon-bearing flows in the CAMP are relatively rare. Therefore, we also have dated sills that are either physically connected to flows as feeders or can be geochemically linked with stratigraphically constrained flows $(18,19)$. In both North American and Moroccan basins, stratigraphic superposition of basalt flows combined with trace element geochemistry provides a relative time scale for the geochemical evolution of CAMP basalts (11, 20-25) (Fig. 3A). This same geochemical trend is also observed in the dated stratigraphically unconstrained units (Fig. 3A). The shared geochemical evolution in CAMP magmas permits correlation between units that share a common trace element signature, allowing the U-Pb date for a stratigraphically unconstrained intrusion to effectively date the horizon of a geochemically similar and stratigraphically constrained basalt flow. This composite geochronologically dated stratigraphic section is used to test the astrochronologic time scale for the Newark basin.

\section{Testing the Astrochronologic Time Scale for the Late Triassic}

The quasiperiodic variations in Earth's orbit, axial direction, and tilt known as Milankovitch cycles result in corresponding variations in the amount and distribution of sunlight reaching Earth. The resulting forcing on climate and/or ocean circulation can influence the characteristics of sediments deposited within a basin, which may ultimately be preserved within the rock record as cyclical variations in rock lithology, chemistry, or isotopic composition (26). CAMP lava flows within the Newark basin of eastern North America (Fig. 2) are interbedded with strikingly cyclical lacustrine strata that have long been hypothesized to be paced by orbital forcing (27). Astrochronologic models for these sequences have been used to estimate the time represented by the sedimentary rocks between CAMP flows, placing high-precision $[ \pm 20$ thousand years (ky)] estimates on the total duration of the CAMP at between 580 and $610 \mathrm{ky}(9,28)$. This proposed "floating" astronomical time scale (ATS) has been met with scrutiny because of the possibility that Earth experienced a different orbital forcing deep in geologic time due to differences in the state of the Earth-Moon system and solar systems dynamics. Further skepticism has focused on whether orbitally forced climatic effects are both accurately recorded and recognized in the geological record. The most straightforward test of the reliability of the ATS is to compare the time durations between basalt flows estimated by orbitally tuning the sedimentary rocks with differences between the zircon U-Pb dates of the flows.

The Orange Mountain Basalt flows are the oldest CAMP lavas in the Newark basin. Although authigenic zircons were not recovered from the Orange Mountain Basalt samples, the flow sequence is partly intruded and fed by an extension of the geochemically identical Palisade sill [201.520 \pm 0.034 million years ago (Ma)] (19).
Based on the ATS for the Newark basin, the overlying flows of the Preakness Basalt should be $250 \pm 20$ ky younger than the Orange Mountain Basalt (and Palisade sill) (9). The U-Pb date of the Preakness Basalt $(201.274 \pm 0.032 \mathrm{Ma})$ results in a difference of $246 \pm 47 \mathrm{ky}$, consistent with the astrochronological estimate. A second interval within the Newark ATS, that again uses the Preakness basalt, can be tested by correlating the Butner diabase from the Deep River Basin (200.916 \pm $0.064 \mathrm{Ma}$ ) to the stratigraphically highest and geochemically similar Hook Mountain Basalt (Fig. 3A). The ATS estimate for the time interval be- tween the base of the Preakness and the base of the Hook mountain basalts is $350 \pm 20 \mathrm{ky}$, a duration consistent with the difference between $\mathrm{U}-\mathrm{Pb}$ dates for the Preakness Basalt and the Butner sheet of $358 \pm 72 \mathrm{ky}$.

A more complete test of the ATS is provided by comparing the astronomical time scale to each of the CAMP flows and intrusions dated here. Using the relative stratigraphy of preserved CAMP flows and the geochemical correlations (Fig. 3A), each stratigraphically unconstrained CAMP intrusive can be correlated to the astronomically tuned Newark Basin. By correlating to the

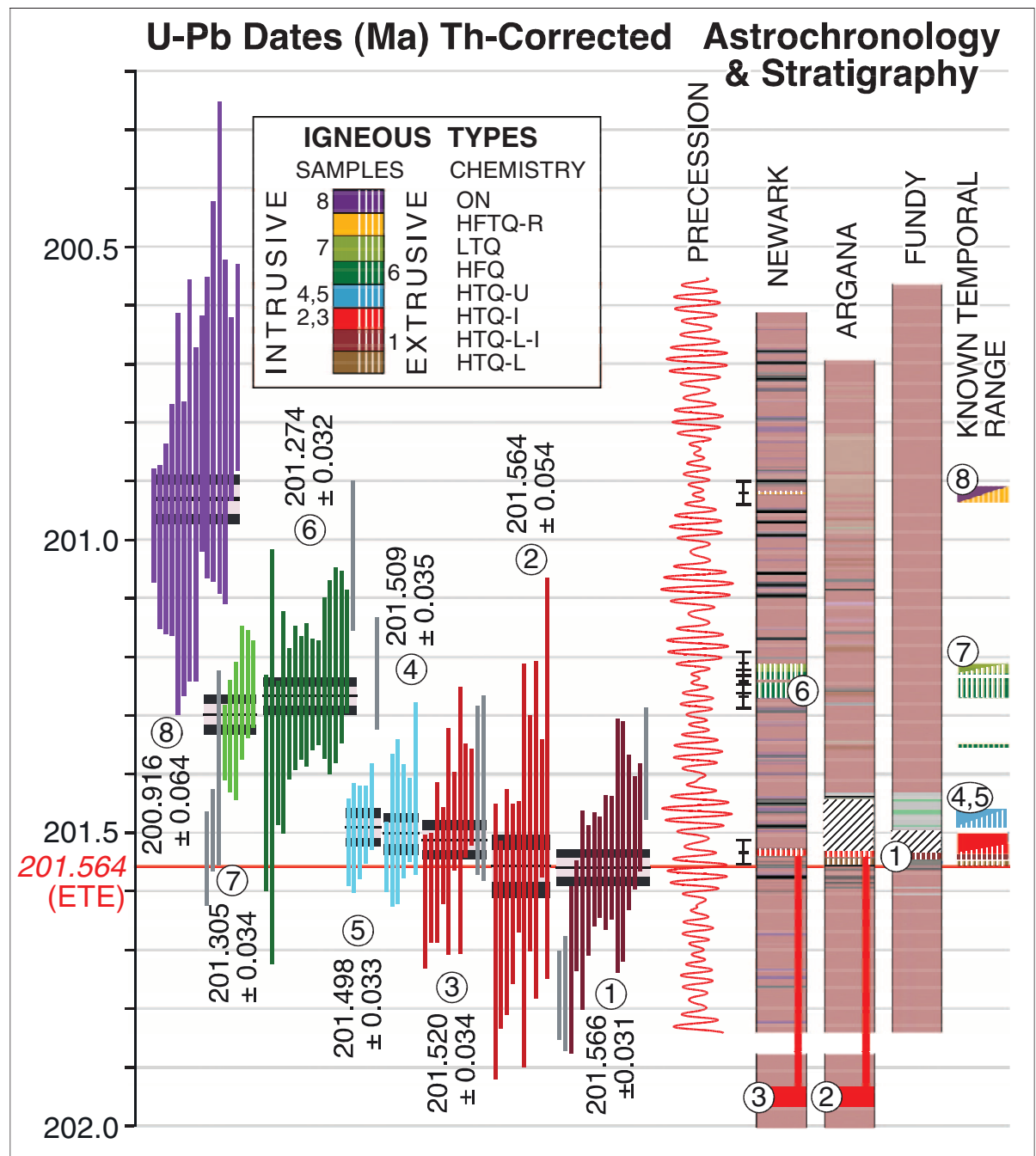

Fig. 2. Zircon U-Pb intercalibration of CAMP volcanism and Early Jurassic Late Triassic astrochronology. Quasiperiodic precessional cyclicity (red) used to generate the ATS $(9,28)$. Within the stratigraphic sections (right), black- and white-hatched regions mark depositional hiatuses, and error bars next to each basalt mark each unit's timing and uncertainty calculated from the ATS. Colored vertical bars (left) represent the ${ }^{238} \mathrm{U}-{ }^{206} \mathrm{~Pb}$ Th-corrected dates (18) for single-crystal zircon analyses at $2 \sigma$, where color indicates basalt chemistry (legend). Legend abbreviations: HTQ, high-titanium quartz normative, includes the lower (L), lower-intermediate (L-I), intermediate (I), and upper (U) units; HFQ, high-iron quartz normative; LTQ, low-titanium quartz normative; HFTQ-R, high-iron-titanium quartz normative or recurrent unit; and ON, olivine normative units. Grayed analyses are excluded from calculated mean dates (18). Sample numbers: 1, North Mountain Basalt; 2, Amelal sill; 3, Palisades sill; 4, York Haven intrusive; 5, Rapidan intrusive; 6, Preakness Basalt; 7, Rossville intrusive; 8, Butner intrusive. Reported dates and black horizontal line mark the weighted mean date, and the outer horizontal box marks the $2 \sigma$ uncertainty. Tabulated data, including a second dated North Mountain Basalt sample, are reported in table S1 (18). 
Newark section, each horizon dated by U-Pb can be placed within the astrochronologic time scale and assigned an estimated time since the ETE (i.e., the extinction horizon that cannot be directly dated by geochronology) (Fig. 3B). Comparing the $\mathrm{U}-\mathrm{Pb}$ geochronology and the durations between the ETE and the dated flows implied by the astronomical tuning reveals that the two chronologies agree well given the analytical uncertainties in the U-Pb dates and the \pm 20 ky uncertainties assigned to the astrochronology. Combining the two data sets (Fig. 3B), the U-Pb dates anchor the higher-precision astrochronology in absolute time, and a least-squares optimization can be used to simultaneously solve for the absolute date of the ETE as well as those of the dated samples that best fit the relative and absolute timing constraints (table S2) (18). This approach yields an estimate of the ETE of $201.564 \pm 0.015 / 0.22 \mathrm{Ma}$, with a

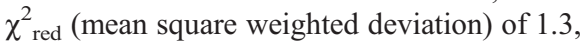
where the first uncertainty reflects analytical uncertainty only and the second includes uncertainty in the ${ }^{238} \mathrm{U},{ }^{232} \mathrm{Th}$, and ${ }^{230} \mathrm{Th}$ decay constants. $\mathrm{U}-\mathrm{Pb}$ geochronologic data are therefore consistent with our geochemical model and assumed correlations and validates the use of the ATS for highresolution astrochronology for the CAMP and ETE time interval. This further indicates that orbital signals were faithfully recorded in these lacustrine strata and that solar system dynamics along with the duration of precession cycles 200 Ma can be reliably modeled (29).

\section{The Relationship Between the Eruption of CAMP and the End-Triassic Extinction}

Integration of geochronologic, geochemical $(11,21-23,25,30)$, paleontological $(9,11,31)$, and magnetostratigraphic $(25,32,33)$ data for the Newark, Fundy, and Argana basins provide the basis for a high-resolution chronology of the earliest known CAMP eruptions and the extinction event (Fig. 4). In each of these sections, the magnetic polarity chron E23r is observed below the sporomorph turnover that marks the terrestrial ETE. The assumed global synchroneity of both magnetic reversals and mass extinctions at the thousandyear level suggests that a common time duration is shared between the horizons marking the base of the E23r and the ETE. If we assume to first order that the thickness of lacustrine strata between these horizons is a proxy for time, the thickness of sedimentary rocks defines the relative duration between the ETE and the lowermost basalts in each basin (Fig. 4). This relative chronology implies that the base of the North Mountain Basalt of the Fundy basin is older than the base of the Orange Mountain Basalt of the Newark basin, whereas the lowermost basalt within the Argana basin (Tasguint Basalt) is older still than the North Mountain Basalt, placing the Tasguint basalt as the oldest CAMP unit. Time estimates on the sedimentary interval from E23r to the lowermost basalt are provided through integration with the astrochronologic time scale for the Newark basin. Within the Newark basin, the base of E23r to the ETE coincides with one climatic precession cycle (2), thus permitting the precession cycle duration to be correlated to the E23r to ETE interval in both the Fundy and Argana basins (Fig. 4). For a 5-millionyear duration of the precession parameter, the average climatic precession cycle is $21.1 \pm 6.1 \mathrm{ky}$ $(2 \sigma)$, with a range of 10 to $31 \mathrm{ky}$. For the Late Triassic-Early Jurassic (200 Ma), that would be $\sim 19.8 \pm 5.7$ ky due to the recession of the Moon (29). Using this model, the ETE is about $13.2 \pm$ 3.8 ky older than the Orange Mountain Basalt (range of 12.9 to $13.5 \mathrm{ky}$, depending on the section). The base of the North Mountain Basalt of the Fundy basin is about $10.0 \pm 2.9$ ky older than the base of the Orange Mountain Basalt, which is $3.2 \pm 0.9$ ky younger than the ETE, and the base of the Tasguint Basalt is $13.2 \pm 3.8$ ky older than the Orange Mountain and $3.2 \pm 0.9$ ky older than the North Mountain Basalt.
Both the turnover in sporomorph taxa marking the terrestrial ETE and an interval of postETE strata is observed below the lowermost basalts in both the Newark and Fundy basins, implying that within these basins CAMP basalts postdate the extinction. The palynological turnover is, however, not observed within the Argana basin, where Triassic sporomorphs are continually observed within sedimentary rocks up to the base of the Tasguint basalt (11). The combined evidence of (i) the older age of the Tasguint basalt relative to basalts in the Newark and Fundy basins, (ii) the astrochronologic time constraints on sediment deposition for the E23rbasalt interval, and (iii) the presence of Triassic sporomorphs beneath the Tasguint basalt, all place the extinction horizon at the base of or within the Tasguint basalt, consistent with the model by Deenen and others (25) but conflicting with chronology of Marzoli and others (11). This chronologic framework permits a causal relationship between CAMP and the ETE to be made at a high level of precision.

Although this temporal link between the eruption of CAMP and ETE strongly imply a causal relationship, how the eruption of CAMP induced a global extinction remains unclear. An emerging model requires the near-instantaneous eruption of large volumes of magma $\left(\sim 8 \times 10^{5} \mathrm{~km}^{3}\right)$ in order to explain (i) the apparent increase of atmospheric $\mathrm{pCO}_{2}$ values $(12,13,34)$; (ii) the near collapse of coral reefs and absence of carbonate deposition, both thought to be triggered by the decrease in the $\mathrm{pH}$ of ocean seawater $(14,15)$; and (iii) the approximately 5-8.5 per mil negative excursion in organic $\delta^{13} \mathrm{C}$ values observed in both marine and terrestrial records, suggesting a large input of isotopically light carbon into the atmosphere (35-37). The subsequent biologic recovery from this extinction is marked within marine sections at the Triassic-Jurassic Boundary (TJB) (38), which is defined at its Global Boundary Stratotype
Fig. 3. Geochemical evolution of CAMP magmas and the comparison between astrochronologic and geochronologic time scales. (A) Geochemical evolution for CAMP units is observed in relative time (stratigraphic column, far left) and in geochronologic time. Included for completeness is the undated Hickory Grove Basalt in the Culpeper basin of Virginia. (B) Using a geochemical correlation between stratigraphically constrained basalts and the dated intrusives (equivalent units), $\mathrm{U}-\mathrm{Pb}$ dates from all dated CAMP units are correlated to the Newark basin and assigned an elapsed time since the ETE. Within the U-Pb and astrochronologic uncertainties, a least-squares optimization reaffirms the reliability of the astrochronologic time scale and the assumptions associated with the geochemical correlation.

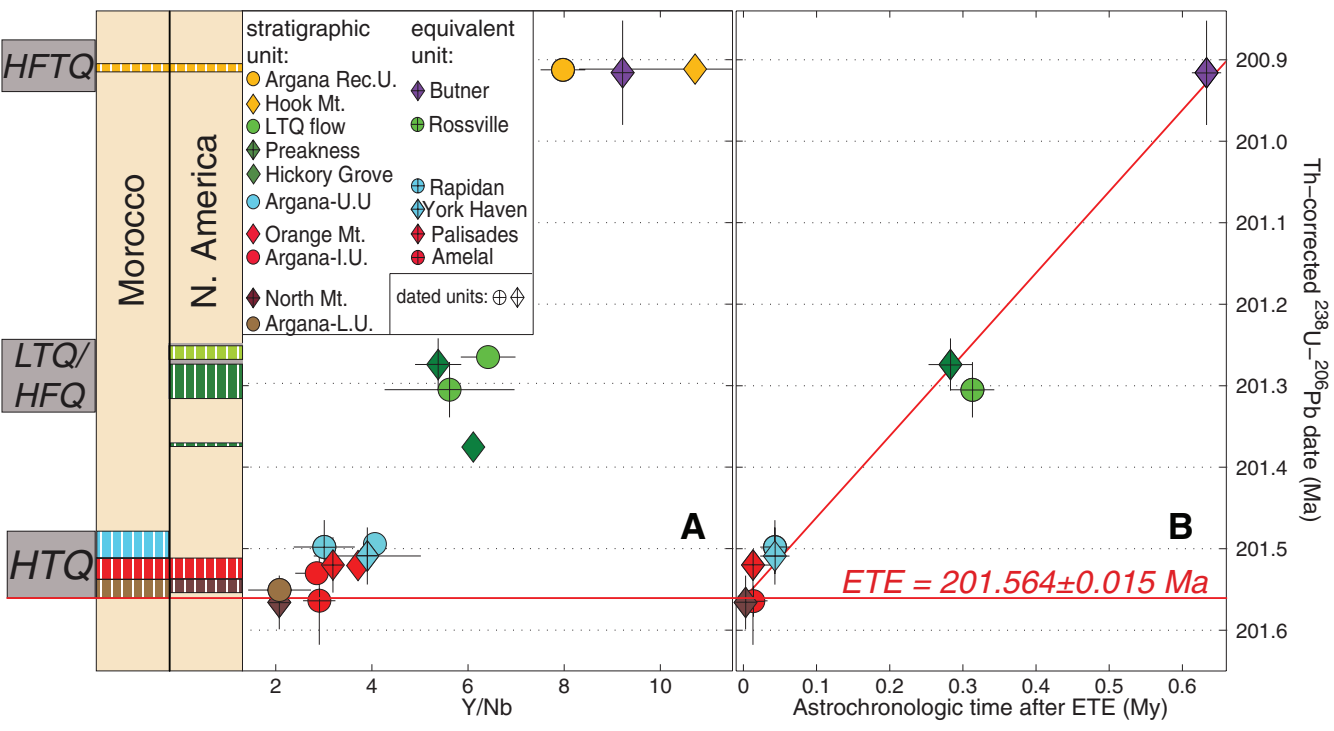

www.sciencemag.org SCIENCE VOL 34024 MAY 2013 


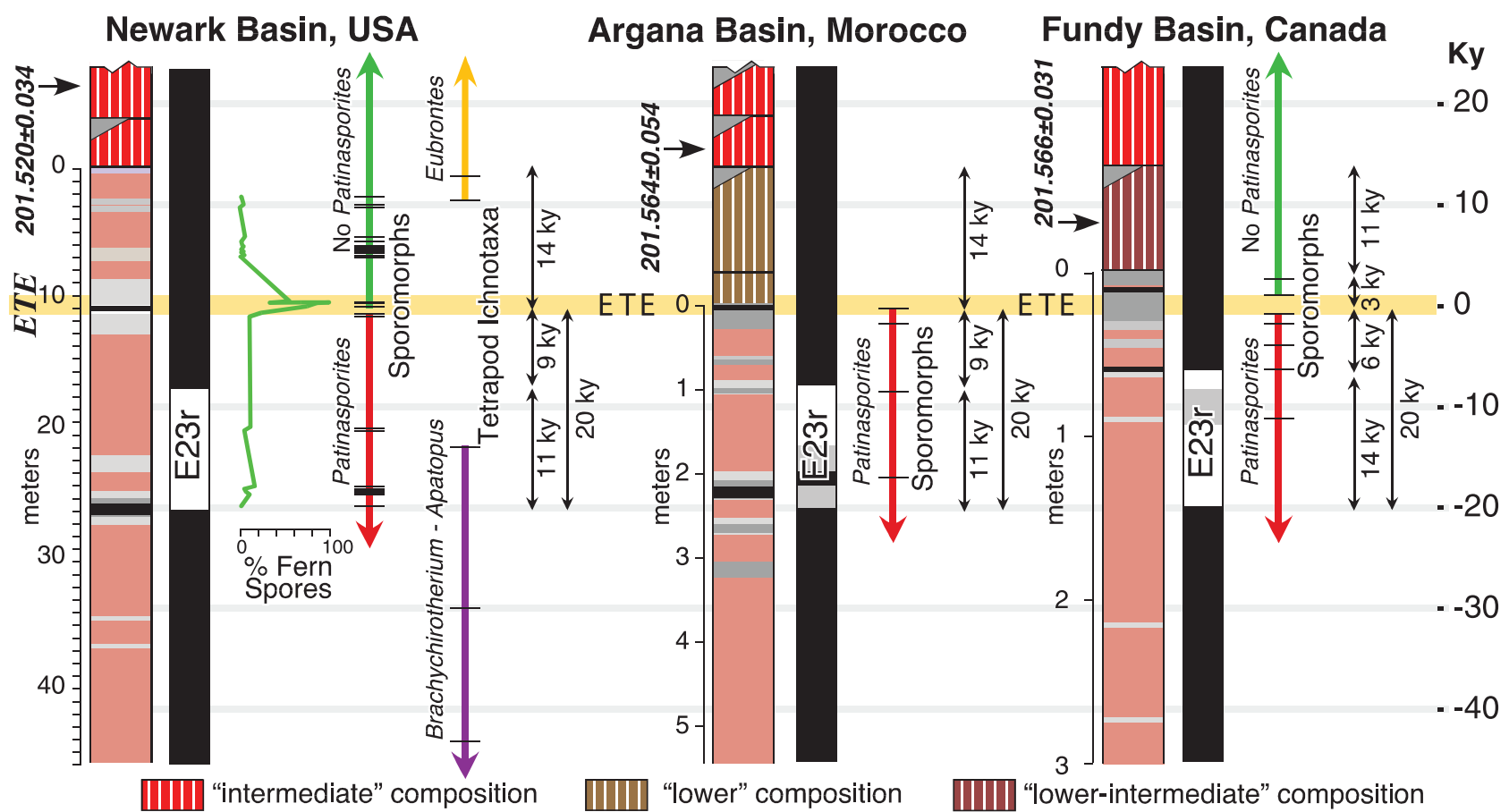

Fig. 4. Integration of geochronologic, magnetostratigraphic, and palynologic data sets for the stratigraphic interval from E23r to the lowermost CAMP basalts in the Newark, Argana, and Fundy basins. Basalt U-Pb dates and magnetic reversal E23r permit correlation between sections. Basalt color correlates to chemistry. Labeled black arrows in-

dicate the astrochronologic time estimates in thousands of years (ky). Palynological data reveal a turnover (green to red arrow transition) in sporomorphs beneath the lower basalt of the Newark and Fundy basin, marking the ETE (yellow horizontal line) at a horizon below the basal CAMP in these basins.
Section and Point (GSSP) as the first appearance of the ammonite Psiloceras spelae (39). At the GSSP and throughout northern Europe (35), correlation to the Newark Basin and the ATS (36) places the TJB at $\sim 100 \pm 40 \mathrm{ky}$ after the ETE (where the large uncertainty derives from problems correlating the marine and terrestrial astrochronologic cycles) and after the eruption of the older, upper high-titanium quartz normative (HTQ-U) basalts. This timeline implies that the biologic recovery associated with the TJB was under way even as subsequent CAMP eruptions and associated pulsed increases in atmospheric $\mathrm{CO}_{2}$ (13) were occurring $\sim 60 \mathrm{ky}$ (HTQ-U), $\sim 270 \mathrm{ky}$ [high-iron quartz normative (HFQ/low-titanium quartz normative (LTQ)], and $\sim 620 \mathrm{ky}$ [highiron-titanium quartz normative (HFTQ-R) after the extinction event (Fig. 3). Because our geochronologic data resolve four discrete CAMP pulses, we propose that it is the first pulse of the "lower" and "intermediate" HTQ chemical groups (Fig. 4) that erupted coincident with and immediately after the ETE that caused the global extinction.

\section{References and Notes}

1. V. E. Courtillot, P. R. Renne, C. R. Geosci. 335, 113 (2003).

2. P. E. Olsen et al., in Catastrophic Events and Mass Extinctions: Impacts and Beyond, C. Koeberl, K. G. MacLeod, Eds. (Geological Society of America Special Paper, Boulder, CO, 2002), vol. 356, pp. 505-522.

3. M. J. Benton, Science 268, 52 (1995).

4. N. Morton, Int Subcomm Jurassic Stratigr Newslett 35, 74 (2008).
5. A. Marzoli et al., Science 284, 616 (1999).

6. B. Schoene, J. Guex, A. Bartolini, U. Schaltegger, T. ]. Blackburn, Geology 38, 387 (2010).

7. G. McHone, Volatile Emissions from Central Atlantic Magmatic Province Basalts: Mass Assumptions and Environmental Consequences (American Geophysical Union, Washington, DC, 2003), vol. 136, p. 14.

8. P. E. Olsen, D. V. Kent, M. Et-Touhami, ]. H. Puffer, in The Central Atlantic Magmatic Province: Insights from Fragments of Pangea, W. E. Hames, G. McHone, P. R. Renne, C. Ruppel, Eds. (Geophysical Monograph Series, 2003), vol. 136, pp. 7-32.

9. ]. H. Whiteside, P. E. Olsen, D. V. Kent, S. ]. Fowell, M. Et-Touhami, Palaeogeogr. Palaeoclimatol. Palaeoecol. 244, 345 (2007).

10. F. Jourdan et al., Lithos 110, 167 (2009).

11. A. Marzoli et al., Geology 32, 973 (2004).

12. J. C. McElwain, D. ]. Beerling, F. I. Woodward, Science 285, 1386 (1999).

13. M. F. Schaller, ]. D. Wright, D. V. Kent, Science 331 1404 (2011).

14. B. Hönisch et al., Science 335, 1058 (2012).

15. S. E. Greene, D. J. Bottjer, F. A. Corsetti, W. M. Berelson, J.-P. Zonneveld, Geology 40, 1043 (2012).

16. A. Robock, Rev. Geophys. 38, 191 (2000).

17. D. Gottfried, L. P. Greenland, E. Y. Campbell, Geochim. Cosmochim. Acta 32, 925 (1968).

18. Materials and methods are available as supplementary materials on Science Online.

19. J. H. Puffer, K. A. Block, J. C. Steiner, J. Geol. 117, 139 (2009).

20. H. El Hachimi, thesis, Cadi Ayyad University, Marrakesh, Morocco (2012).

21. D. Gottfried, A. Froelich, J. N. Grossman, "Geochemical data for Jurassic diabase associated with early Mesozoic basins in the eastern United States; Gettysburg Basin and vicinity, Pennsylvania and Maryland," Open-File Report 91-322-E (USGS, Washington, DC, 1991); http://pubs.er. usgs.gov/publication/ofr91322E.
22. D. Gottfried, A. Froelich, ]. N. Grossman, "Geochemical data for Jurassic diabase associated with early Mesozoic basins in the eastern United States; Culpeper Basin and vicinity, Virginia and Maryland," Open-File Report 91-322-F (USGS, Washington, DC, 1991); http://pubs.er. usgs.gov/publication/ofr91322F.

23. D. Gottfried, A. Froelich, ]. N. Grossman, "Geochemical data for Jurassic diabase associated with early Mesozoic basins in the eastern United States; western Newark Basin, Pennsylvania and New Jersey," Open-File Report 91-322-C (USGS, Washington, DC, 1991); http://pubs.er. usgs.gov/publication/ofr91322C.

24. R. P. Tollo, D. Gottfried, Spec. Pap. Geol. Soc. Am. 268 233 (1992).

25. M. H. L. Deenen et al., Earth Planet. Sci. Lett. 291, 113 (2010).

26. L. A. Hinnov, J. G. Ogg, Stratigraphy 4, 239 (2007).

27. F. B. VanHouten, Am. J. Sci. 260, 561 (1962).

28. P. E. Olsen, D. V. Kent, Palaeogeogr. Palaeoclimatol. Palaeoecol. 122, 1 (1996).

29. A. Berger, M. Loutre, J. Laskar, Science 255, 560 (1992).

30. J. N. Grossman, D. Gottfried, A. J. Froelich, "Geochemical data for Jurassic diabase associated with Early Mesozoic Basins in the eastern United States," Open-File Report 91-322-] (USGS, Washington, DC, 1991); http://pubs.er usgs.gov/publication/ofr91322].

31. S. Cirilli et al., Earth Planet. Sci. Lett. 286, 514 (2009)

32. D. V. Kent, P. E. Olsen, J. Geophys. Res. 104 (B6), 12831 (1999).

33. M. H. L. Deenen, W. Krijgsman, M. Ruhl, ].-C. Mareschal, Can. J. Earth Sci. 48, 1282 (2011).

34. M. R. Rampino, K. Caldeira, Science 334, 594, author reply 594 (2011).

35. S. P. Hesselbo, S. A. Robinson, F. Surlyk, S. Piasecki, Geology 30, 251 (2002).

36. J. H. Whiteside, P. E. Olsen, T. Eglinton, M. E. Brookfield, R. N. Sambrotto, Proc. Natl. Acad. Sci. U.S.A. 107, 6721 (2010).

37. M. Ruhl, N. R. Bonis, G.--]. Reichart, ]. S. Sinninghe Damsté, W. M. Kürschner, Science 333, 430 (2011). 
38. A. Bartolini et al., Geochem. Geophys. Geosyst. 13, Q01007 (2012).

39. A. von Hillebrandt, L. Krystyn, Geologie und Palontologie 253, 163 (2009)

40. D. V. Kent, L. Tauxe, Science 307, 240 (2005).

Acknowledgments: We express our gratitude to S. Burgess, N. Youbi, B. Schoene, ]. Ramezani, D. Condon, and two anonymous reviewers. We acknowledge that this work owes much to the collective effort of the EARTHTIME community. We also thank Vulcan Materials and Carolina Sunrock LLC for quarry access, G. Fisher of the Alcatel-Lucent EH\&S-Americas for Preakness Basalt cores, B. Smith for the Rossville and York Haven diabase samples, and ]. Smoot and N. Ratcliff for access to cores and thin sections. We acknowledge support from the U.S. National Science Foundation (grants EAR-0446880 and EAR-0931839 to S.A.B., EAR 0753496 to P.E.O. and D.V.K., and EAR 0345664 to E.T.R.). P.E.O received support from the Bahamas Petroleum Company. Data presented in this paper are fully documented in the supplementary materials. U-Pb zircon data are deposited at the Geochron database (www.geochron.org) with SESAR IGSNs SAB000002-SAB00000A, available at www.geochron.org/ dataset/htmL/5QISoX9SCt]bNfOZbNeXtuwSK.

\section{Supplementary Materials}

www.sciencemag.org/cgi/content/full/science.1234204/DC1

Materials and Methods

Supplementary Text

Figs. $\mathrm{S} 1$ to $\mathrm{S5}$

Tables S1 to S3

References (41-92)

18 December 2012; accepted 28 February 2013

Published online 21 March 2013;

$10.1126 /$ science 1234204 


\title{
Science
}

\IAAAS

\section{Supplementary Materials for}

\section{Zircon U-Pb Geochronology Links the End-Triassic Extinction with the Central Atlantic Magmatic Province}

Terrence J. Blackburn, * Paul E. Olsen, Samuel A. Bowring, Noah M. McLean, Dennis V. Kent, John Puffer, Greg McHone, E. Troy Rasbury, Mohammed Et-Touhami

\author{
*Corresponding author. E-mail: TBlackburn@ciw.edu \\ Published 21 March 2013 on Science Express \\ DOI: $10.1126 /$ science. 1234204
}

This PDF file includes:

Materials and Methods

Supplementary Text

Figs. S1 to S5

Tables S2 and S3

References (41-92)

Other Supplementary Material for this manuscript includes the following:

(available at www.sciencemag.org/cgi/content/full/science.1234204/DC1)

Table S1 (.xls file) 


\section{Materials and Methods}

Laboratory Methods

Each reported zircon $\mathrm{U}-\mathrm{Pb}$ crystallization age is a weighted mean of measured ${ }^{238} \mathrm{U}$ ${ }^{206} \mathrm{~Pb}$ dates that have been corrected for initial ${ }^{230} \mathrm{Th}$ disequilibrium. Uncertainties are reported using the notation $\pm X / Y / Z$ where $X$ is the analytical uncertainty alone, $Y$ the analytical uncertainty and uncertainty derived from tracer calibration and $Z$ these previous uncertainties plus those derived from the uncertainty on the ${ }^{238} \mathrm{U}$ decay constant. The uncertainties reported within the text are analytical uncertainties alone. For the purpose of calculating a difference in time between two layers dated using the same tracer solution and same radiometric system, only the analytical uncertainties need be propagated. However if these data are to be compared to U-Pb data from other labs with different tracers or other systems (e.g. ${ }^{40} \mathrm{Ar} /{ }^{39} \mathrm{Ar}$, Fig. S1) the uncertainty in the tracer calibration and the tracer calibration plus decay constant must be propagated, respectively.

Testing the temporal estimates on CAMP provided by astrochronology requires that at least two individual horizons within the sedimentary sequence be dated by radioisotope geochronology. The difference in time with uncertainties between the two horizons determined by geochronology and astrochronology can then be compared. The astrochronologic models yield estimates on the amount of time between the oldest two major pulses of CAMP magmatism in eastern North America of $250 \mathrm{ky}$ (1). To test for a difference of $250 \mathrm{ky}, 200$ million years ago requires radioisotopic dates between horizons with analytical uncertainties an order of magnitude smaller than the time difference. Though there are several accessory phases found in mafic rocks amenable to U-Pb dating (zircon, baddeleyite, zirconolite, titanite), only zircon is capable of yielding the level of precision and accuracy required to test the duration of CAMP. Zircon $\left(\mathrm{ZrSiO}_{4}\right)$ is not as common in mafic rocks as in intermediate to felsic rocks. However primary zircon is found in coarse-grained mafic gabbroite, pegmatoidal or granophyric segregations within both gabbroic sills and thick thoeliitic flows of CAMP. In this study, eight zircon-bearing CAMP rocks have been dated using $\mathrm{U}-\mathrm{Pb}$ methods.

Zircons were separated using standard rock crushing and mineral separation techniques. Single grain zircon analyses were dated using the Chemical Abrasion or CATIMS method (2). All zircons were dissolved with the isotopic tracer solution ET2535 containing ${ }^{202} \mathrm{~Pb},{ }^{205} \mathrm{~Pb},{ }^{233} \mathrm{U}$ and ${ }^{235} \mathrm{U}$. Use of the two enriched isotopes of $\mathrm{Pb}\left({ }^{202} \mathrm{~Pb}-{ }^{205} \mathrm{~Pb}\right)$ and $U\left({ }^{233} \mathrm{U} /{ }^{235} \mathrm{U}\right)$ in the tracer solution allows for enhanced accuracy in the determination of mass-dependent fractionation of both elements within the mass spectrometer during analysis. The decreased uncertainty from using the ${ }^{202} \mathrm{~Pb}-{ }^{205} \mathrm{~Pb}$ tracer leads to a lower propagated uncertainty on an individual date with total uncertainties on mean error-weighted dates improved by up to $\pm 20 \mathrm{ky}(0.01 \%)$ for the CAMP data presented here. All dates are calculated using an isotopic composition of uranium $\left({ }^{238} \mathrm{U} /{ }^{235} \mathrm{U}\right)$ of $137.818 \pm 0.045$ (2! ) (3). For the zircon U-Pb CAMP data, the variation in uranium isotopic composition $\left({ }^{238} \mathrm{U} /{ }^{235} \mathrm{U}\right)$ required to change $\mathrm{a}{ }^{238} \mathrm{U}-{ }^{206} \mathrm{~Pb}$ date by just $1 \mathrm{ky}$, are on the order of $+0.05 /-0.13$. This range in uranium isotopic compositions is outside the observed range for uranium in zircons (3). Uranium was analyzed as an oxide, assuming and ${ }^{18} \mathrm{O} /{ }^{16} \mathrm{O}$ composition of 0.00205 . Grayed analysis shown in figure 2 are statistical outliers and not included in mean date calculations, as they likely were 
influenced by lead-loss (younger dates), or minor zircon inheritance (older dates). Use of EARTHTIME tracer solutions allows a datum produced by this study to be compared to data from other labs using EARTHTIME tracers without propagating the uncertainty derived from tracer calibration. All U-Pb data were reduced using the Tripoli and U_Pb_Redux software packages and EARTHTIME tracer calibration (v. 3.0) $(4,5)$.

\section{Samples}

Basalts and gabbroic portions of sills from the CAMP were sampled in eastern North America from North Carolina to Nova Scotia and within the Argana basin, Morocco. Sample collection focused on identifying coarse-grained layers or segregations within basalts and gabbros. As these large intrusive and extrusive bodies undergo fractional crystallization, residual liquid is physically isolated into layers or lenses through either the compaction or buoyancy driven separation (6-8). Zirconium is an incompatible element and will remain within the melt until such time that sufficient silica activity allows for zircon to form, which in most cases has relatively high concentrations of $U$. The zircons that crystallize within these segregations are morphologically distinct and typical zircons analyzed in this study have a blocky aspect ratio (sizes) without terminations and often a weak discoloration and occasionally melt or baddeleyite inclusions oriented parallel with the c-axis (Fig. S2).

The eight CAMP bodies dated in this study are from gabbroids from intrusions and flows that are from north to south: 1) the Amelal sill found to feed the Alemzi basalt (i.e. the upper Argana Basalt), Argana Basin, Morocco, (201.564 0 0.054/0.075/0.23, MSWD = 0.93); 2) the East Ferry Member of the North Mountain Basalt (flow) of the Fundy basin, Nova Scotia (dated at 2 locations, 201.566 0.031/0.061/0.22, MSWD = 1.4 and 201.522 $\pm 0.064 / 01.4 / 1.4$, MSWD $=0.71$ ); 3) the Palisade sill (intrusive) of the Newark basin, New Jersey $(201.515 \pm 0.033 / 0.02 / 0.22$, MSWD = 1.7) ; 4) the "second flow" (following Tollo and Gottfried (9)) of the Preakness Basalt of the Newark basin in New Jersey $(201.274 \pm 0.032 / 0.062 / 0.22$, MSWD $=0.71)$; 5) the Rossville Diabase, Rossville Pennsylvania (201.305 $\pm 0.034 / 0.063 / 0.22$, MSWD = 1.4); 6) the York Haven Diabase, York Haven, Pennsylvania (201.509 $\pm 0.035 / 0.063 / 0.22, \mathrm{MSWD}=0.77)$; 7$)$ the Rapidan sheet (intrusive) of the Culpepper Basin in Virginia (201.498 \pm $0.033 / 0.062 / 0.22$, MSWD = 0.44); and 8) the Butner olvine diabase sheet (intrusive) of the Deep River basin, North Carolina (200.916 $\pm 0.064 / 0.075 / 0.23$, MSWD = 1.5) (Fig. 2). Single grain zircon $\mathrm{U}-\mathrm{Pb}$ data for each CAMP unit are tabulate in Table $\mathrm{S} 1$, while the least squared optimized date, calculated using the astrochronologic constraints, are tabulated in Table S2.

There have been several previous geochronologic studies of CAMP, using both ${ }^{40} \mathrm{Ar} /{ }^{39} \mathrm{Ar}$ and $\mathrm{U}-\mathrm{Pb}$ techniques and applied to samples from a much larger geographic distribution than this study. Most of this work has used ${ }^{40} \mathrm{Ar} /{ }^{39} \mathrm{Ar}$ dating of groundmass plagioclase separates from CAMP basalts and sills. Calculated plateau, "mini-plateau" and isochron dates are typically cited with 2 ! analytical uncertainties on the order of $\sim 1-2$ My. Analyses of ground mass plagioclase are often susceptible to Ar-recoil (10) or excess $\operatorname{Ar}(11,12)$, however, the low parent to daughter ratio is likely a key component of the relatively high uncertainty reported on measured dates. A comparison between CAMP ${ }^{40} \mathrm{Ar} /{ }^{39} \mathrm{Ar}$ and $\mathrm{U}-\mathrm{Pb}$ data from Eastern North America inevitably reveals a $1-1.5 \%$ age bias, linked to the uncertainties on the age of neutron flux monitoring standards and the 
decay constants for ${ }^{40} \mathrm{~K}(13)$. Two new methods for the independent re-determination of the Fish Canyon Tuff (FCT) standard date $(13,14)$ and ${ }^{40} \mathrm{~K}$ decay constants $(13,15,16)$ allow for recalculated CAMP ${ }^{40} \mathrm{Ar} /{ }^{39} \mathrm{Ar}$ data sets to be better compared with $\mathrm{U}-\mathrm{Pb}$ data. Though use of the revised decay constant and FCT values apparently eliminates the systematic bias, the analytical uncertainty alone on each $\sim 200 \mathrm{Ma}{ }^{40} \mathrm{Ar} /{ }^{39} \mathrm{Ar}$ date (e.g $\pm 1-$ $3 \mathrm{My}$ ) is typically ten times greater than the analytical uncertainty associated with a single grain $\mathrm{U}-\mathrm{Pb}$ zircon date (e.g $\pm 100 \mathrm{ky}$ ) and over a full order of magnitude larger than the weighted mean date of the U-Pb zircon data (e.g $\pm 30 \mathrm{ky}$ ) (Fig. S1). Evaluating the accuracy of astrochronological constraints on CAMP requires precision on individual dates less than the total duration of CAMP and ideally less than a single precessional cycle. For these reasons $\mathrm{U}-\mathrm{Pb}$ zircon geochronology is the only way to approach this problem.

Previous U-Pb geochronologic data from CAMP include a study by Dunning and Hodych (17), where zircon and baddeleyite $\mathrm{U}-\mathrm{Pb}$ analyses produced $\mathrm{a}^{238} \mathrm{U}-{ }^{206} \mathrm{~Pb}$ date for

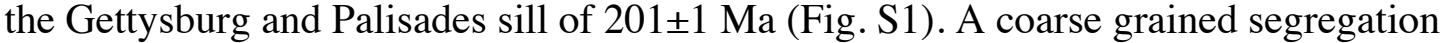
from the North Mountain Basalt in the Fundy Basin, Nova Scotia was dated by Hodych and Dunning (18) who reported a ${ }^{238} \mathrm{U}_{-}{ }^{206} \mathrm{~Pb}$ age of $202 \pm 1 \mathrm{Ma}$. These studies employed air-abrasion techniques and were not corrected for ${ }^{230} \mathrm{Th}$ disequilibrium. The same unit was analyzed by Schoene and others (19) where air abraded zircons were dated using IDTIMS yielding a non-thorium corrected ${ }^{238} \mathrm{U}^{206} \mathrm{~Pb}$ age of $201.27 \pm 0.03 \mathrm{Ma}$. More recently Schoene and others (20), published a new date for the North Mountain basalt, from zircons dated by CA-TIMS (2) 201.38 $0.02 \mathrm{Ma}$ (using EARTHTIME tracer calibration v.1.0) (Fig. S1). We present here, new North Mountain basalt zircon analyses using the most recent EARTHTIME tracer calibration (v. 3.0)

Feeder relationship between the Palisade sill and the Orange Mountain Basalt

A discordant segment of the Palisade sill is in contact and interpreted to have fed basalt flows at the northeast terminus of the Newark basin in Ladentown, New York (21) and allows the date of the Palisades sill to be equivalent to that of the Orange Mountain Basalt (Fig. 3). The detailed major and trace element chemistry of the flows is identical to the this segment of the Palisade sill ( 6 ). In addition, the Palisades sill also intrudes the locally lowest flow at Ladentown. However, Ratcliffe (21) argued that while the Palisade sill did feed the Ladentown flows they did so after extrusion of the Orange Mountain Basalt. Ratcliffe's argument was based on the presence of presumed basalt clasts below the Union Hill basalt in Suffern, New York and basalt clasts in metamorphosed conglomerate in contact with the Palisade sill close to the Ladentown flows. Ratcliff concluded that because the Orange Mountain Basalt is the oldest known flow in the basin, these conglomerates must postdate it and thus the Palisades sill and the Ladentown flows must postdate the Orange Mountain Basalt, despite having identical chemistry.

Five sets of observations argue against at least the lowest Ladentown flow postdating the Orange Mountain basalt. First, no basalt clasts have been found below the Ladentown flows themselves either in core or adjacent outcrops. Second, the Union Hill basalt flows are Preakness Basalt, displaying the distinctive stratigraphy characteristic of Preakness flows 1 and 2 (9) consisting of a lower thin pillowed flow overlain by a massive and thick, splintery fractured flow, both with Preakness Basalt chemistry (21), and the simplest interpretation is that they represent an outlier of the Preakness Basalt and 
are not equivalent to the flows at Lademtown. Third, the conglomerate underlying the Union Hill flows is Feltville Formation, but the brownish lithology looks unlike the more brick red conglomerates below the Ladenton flows, which more closely resemble typical Passaic Formation. Fourth, the basalt clasts in the conglomerate in the metamorphic aureole of the Palisade sill consist of one apparently igneous millimeter-scale grain that could be sourced from the adjacent mafic Rosetown igneous complex instead of the Orange Mountain Basalt (Ratcliffe, pers. comm., 2011). Fifth, if the contact metamorphic aureole rocks with the basalt clasts were Feltville Formation, it requires the Feltville to thicken enormously towards the north, in the same direction all the other units appear to be thinning. All of these observations argue that the simplests interpretation of the Ladentown flows is that they are an outlier of Orange Mountain Basalt.

Gray and black lithologies lie between the two Ladentown flows in the Haverstraw Road core (21). The sedimentary interbed between the flows could be basal Feltville Formation, in which case the succeeding flow could still slightly postdate the rest of the Orange Mountain Basalt, or it could be a local interbed between Orange Mountain flows. There is insufficient stratigraphic and geochemical data to discriminate between these two hypotheses, but in any case, we can conclude that at least the lowest flow at Ladentown is Orange Mountain Basalt, in agreement with the chemistry.

The chemistry of the sampled pegmatitic unit within the Palisade sill is also consistent with a common magma for it and the Orange Mountain Basalt $(6)$, as opposed to younger pulses of magma into the Palisade sill. Thus, the zircon date from the Palisade sill should be representative of the Orange Mountain Basalt. An important test of this hypothesis is the high-precision geochronologic data presented here for the North Mountain Basalt and Palisades sill.

Feeder relationship between the Amelal sill and the Alemzi Formation flows, Argana Basin, Morocco

The Amelal sill is a thoeliitic sill intrusive into the Bigoudine Formation in the southern Argana basin. Long of uncertain affinities, El Hachimi (22) argued, based on chemistry that the sill is indistinguishable from the structurally overlying Alemzi Formation of lava flows and that the sill was a feeder to the latter flows. In October 2012, MET and PEO conduced fieldwork to determine the physical relationship between the sill and the Argana basalts. Field observations show that the sill postdates and intrudes the Tasguint Formation, but predates or feeds the overlying Alemzi Formation flows as follows: 1) at the north end of the sill near the village of Sgat at least parts of the sill intrude and metamorphose the Tasguint Formation; 2) this metamorphism is most obvious in the effects on the ubiquitous generally red sedimentary rock-filled fissures and voids in the Tasguint Formation and where the sill intrudes the latter, these normally red post-Taguint units are metamorphosed to white hornfels; 3 ) in contrast, similar sedimentary rock-filled fissures and voids in the directly overlying Alemzi Formation as well as the post-Alemzi Formation strata are completely unaffected and remain red. The simplest interpretation of these observations is that the Amelal sill fed the Alemzi Formation flows, although the vent itself remains to be located.

${ }^{238} \mathrm{U}_{-}{ }^{206} \mathrm{~Pb}$ age correction for initial $\underline{230} \underline{\mathrm{Th}} \underline{\text { disequilibrium }}$ 
The U-Pb dates used in our analysis are thorium-corrected, weighted mean ${ }^{238} \mathrm{U}$ ${ }^{206} \mathrm{~Pb}$ dates. The thorium correction accounts for the preferential exclusion of an intermediate daughter product $\left({ }^{230} \mathrm{Th}\right)$ in the ${ }^{238} \mathrm{U}$ decay chain from the zircon crystal and the resulting deficiency in ${ }^{206} \mathrm{~Pb}$. The zircon $\mathrm{Th} / \mathrm{U}$ value is calculated from the measured ${ }^{208} \mathrm{~Pb} /{ }^{206} \mathrm{~Pb}$ ratio assuming concordance between the ${ }^{232} \mathrm{Th}-{ }^{208} \mathrm{~Pb}$ and the ${ }^{238} \mathrm{U}-{ }^{206} \mathrm{~Pb}$ systems. The distribution coefficients for Th and $\mathrm{U}$ partitioning in zircon are calculated from the zircon $\mathrm{Th} / \mathrm{U}$ and an assumed or estimated magmatic $\mathrm{Th} / \mathrm{U}$. Key to an accurate correction for the exclusion of intermediate daughter products is a reliable estimate for the $\mathrm{Th} / \mathrm{U}$ ratio of the magma from which the zircon crystallized. In the absence of melt inclusions we rely on whole rock $\mathrm{Th} / \mathrm{U}$ as a reasonable estimate of magmatic $\mathrm{Th} / \mathrm{U}$. A compilation of $686 \mathrm{Th} / \mathrm{U}$ measurements from CAMP rocks worldwide yields an average $\mathrm{Th} / \mathrm{U}$ of $4.2 \pm 0.2$ (2! ) (23-30). However, the physical and chemical processes required to concentrate incompatible elements leading to the crystallization of zircon suggest that whole rock measurements of $\mathrm{Th} / \mathrm{U}$ are unlikely to represent the composition of late stage melts from which the zircon crystallized. Comparisons between the thorium and uranium concentrations of the chilled margins and granophyres at the centers of flows find that though the $U$ and $T h$ concentration increase towards the coarse grain center, while the $\mathrm{Th} / \mathrm{U}$ value remains constant throughout the segregation process at values of $\sim 4.0(31)$. This measured data can be further supported by models designed to predict the $\mathrm{Th} / \mathrm{U}$ evolution of a CAMP magma. Beginning with the whole rock Th/U composition of 4.0 combined with petrologic descriptions $(7,32,33)$ can be used to develop a crystallization sequence for CAMP magmas, which in turn can be used as an input into a model describing the $\mathrm{Th} / \mathrm{U}$ evolution within a crystallizing magma. The mass balance equation capable of describing the $\mathrm{Th} / \mathrm{U}$ ratio of an evolving magma is:

$\frac{T h}{U}_{\text {magma }}=\frac{T h}{U_{\text {initial }}} \cdot \frac{F+D_{\text {bulk }}^{U} \cdot(1-F)}{F+D_{\text {bulk }}^{T h} \cdot(1-F)}$,

where $F$ is the fraction of crystals in the magma, $T h / U_{\text {initial }}$ is the initial or whole rock measurement. The bulk partition coefficient $\left(D_{b u l k}\right)$ for either uranium or thorium given by:

$D_{\text {bulk }^{\text {elent }}{ }_{a}}^{\text {end }}=D_{\text {phase }_{i}}^{\text {elent }_{a}} \cdot x_{\text {phase }_{i}}+D_{\text {phase }_{j}}^{\text {element }_{a}} \cdot x_{\text {phase }_{j}}$,

where $D_{\text {phase }}$ describes the partition coefficient for a specific mineral in a basaltic liquid and $x_{\text {phase }}$ describes the fraction of that mineral within the rock. Experimentally and empirically determined partition coefficients for uranium and thorium of minerals quartz, plagioclase, pyroxene, ilmenite, magnetite and apatite are used to predict the potential fractionation of Th from $U$ during the crystallization sequence of a CAMP magma (Table S3) (34-49). Modal abundances of these minerals reported for a variety of CAMP flows and sills are input for the fraction of a mineral $\left(x_{\text {mineral }}\right)$ (Table S3) $(7,8)$ (Fig. S3). In major phases plagioclase, pyroxene and Fe-Ti oxides, both uranium and thorium are highly incompatible and do not fractionate until low remaining melt fractions $(\mathrm{F}<0.2)$. Pyroxene, feldspars and Fe-Ti however, constitute up to $70 \%$ or more of the coarse grain segregation sheets or granophyres (8), concentrating the remaining $\mathrm{U}$ and $\mathrm{Th}$ 
(unfractionated) within the interstitial mesostasis. This remaining interstitial magma or mesostasis crystallizes as fine grain pyroxene, feldspar, quartz, magnetite, apatite and glass $(7,8,32,33)$. In these remaining trace phases thorium is either not fractionated from uranium (glass, magnetite, pyroxene) or uranium is preferentially incorporated into the solid over thorium (plagioclase), increasing the melt $\mathrm{Th} / \mathrm{U}$ from which zircon can crystallize from (Fig S3). The crystallization of zircon, which the model does not consider, would only reinforce this trend. Apatite crystlization may have the opposite effect. Using reported phosphorous concentrations to establish a maximum limit on modal apatite suggests this amount $(<0.004 \%)$ results in minimal fractionation of thorium from uranium. In total this model permits a minimum estimate of the initial value of the residual magma $\mathrm{Th} / \mathrm{U}$ from which zircon will crystallize.

The magnitude of the ${ }^{238} \mathrm{U}-{ }^{206} \mathrm{~Pb}$ Th-correction is correlated with the difference between a zircon and whole rock $\mathrm{Th} / \mathrm{U}$ (Fig S4). The large difference in $\mathrm{Th} / \mathrm{U}$ between CAMP whole rock data (>4.0) and CAMP zircons (1.3-2.5) results in a correction that is insensitive to the value of the melt composition at $\mathrm{Th} / \mathrm{U}$ values above $\sim 3.5$. The fractional crystallization histories that lead to crystallization of zircon in these magmatic bodies are accompanied by a fractionation in $\mathrm{Th} / \mathrm{U}$ that will only increase the initial whole rock $\mathrm{Th} / \mathrm{U}$ value. The fact that whole rock $\mathrm{Th} / \mathrm{U}$ values serve as a minimum value ensures that the magnitude of $\mathrm{Th} / \mathrm{U}$ correction is nearly constant yielding the ${ }^{238} \mathrm{U}-{ }^{206} \mathrm{~Pb}$ Thorium corrected age plateau observed in figure S4. Tabulated data (Table S1) and data reported in figure 1 and the main text are calculated assuming a magmatic Th/U of 4.0.

\section{Estimating Zircon-magma residence times}

The U-Pb system in zircons is chemically and physically robust chronometer that behaves as a closed system in nearly all cases (i.e. $\mathrm{U}$ and $\mathrm{Pb}$ are retained). As a result, the dates of magmatic zircon reflect the time spent within a magma chamber prior to eruption/intrusion and cooling. We can evaluate the time-scales of magma chamber residence recorded by the $\mathrm{U}-\mathrm{Pb}$ in zircon system by utilizing a thermal half-space model to simulate the cooling history of a typical CAMP magmatic body. Contrary to the suggestion by Jourdan and others (50) that zircons derived from CAMP bodies have experienced prolonged magma residence, zircons within the CAMP gabbros and basalts are the result of in-situ fractional crystallization, and not any pre-emplacement magmatic processes (i.e. zircon crystallization at depth). This is supported by petrologic (51) and field observations for the physical segregation of residual melts within these magmatic bodies $(8,51)$ and the concentration of $\operatorname{Zr}(31)$. The measured dimensions of the CAMP flows, sills and dikes can be input directly into a 1-D conductive half-space model to place a rough estimate on the the time-scales of cooling and zircon residence (Fig. S5). Model parameters include a initial temperature of $1300^{\circ} \mathrm{C}$ and a maximum flow or sill thickness as measured from the thickest dated bodies, the Preakness basalt flow $(200 \mathrm{~m})$ and Palisades sill $(300 \mathrm{~m})$. This model further assumes instantaneous magma emplacement and that cooling begins once magmatic additions to a flow have ceased. We can examine the segment of the $\mathrm{t}-\mathrm{T}$ path from magmatic temperatures to the minimum temperatures anticipated for crystallization of zircon $\left(\sim 900\right.$ and $\left.600{ }^{\circ} \mathrm{C}(52)\right)$. Results indicate that cooling from the intrusive temperatures below the temperatures anticipated for zircon crystallization occurs within 100 years for a basalt flow and 2000 years within the sills. These time-scales are consistent with estimates for basalt cooling that calculates 
the rate of upper crust growth due to cooling (53). These results suggest that the magma residence time of zircons within the basaltic flows and dikes are insignificant and far below the resolution of the U-Pb data. 


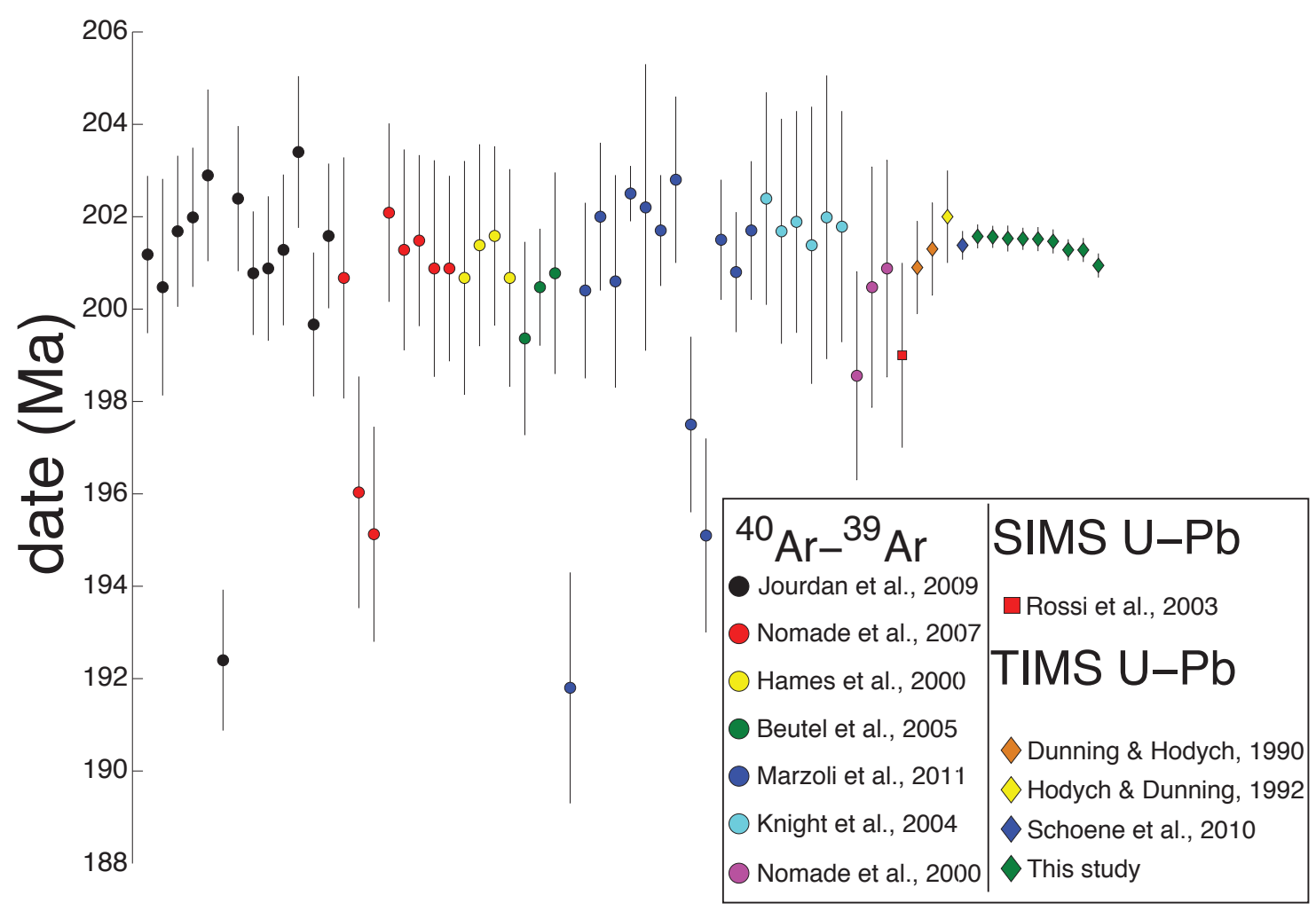

\section{Fig. S1.}

Comparison between ${ }^{40} \mathrm{Ar}^{39} \mathrm{Ar}$ (previously published) $(50,54-58)$ and $\mathrm{U}-\mathrm{Pb}$ zircon data by both SIMS (Secondary Ion Mass Spectrometry) (59) and TIMS (Thermal Ionization Mass Spectrometry) (previously published $(17,18,20)$ and data presented here (Fig. 2)) for CAMP related basalt flows and intrusions from the Eastern US and Morocco. Our goals to evaluate the cyclostratigraphic model for sediment accumulation in the Newark basin and to evaluate a potential causal relationship between the end Triassic extinction event and CAMP requires geochronologic data with uncertainties much less than time estimates for the duration of flood basalt volcanism $(\sim 620 \mathrm{kyr})$ and ideally approaching orbitally forced cycle duration. The large uncertainties associated with dates produced by ${ }^{40} \mathrm{Ar}-{ }^{39} \mathrm{Ar}$ or SIMS U-Pb makes them unsuitable for either of the goals and requires highprecision CA-TIMS zircon geochronology . All ${ }^{40} \mathrm{Ar}^{39} \mathrm{Ar}$ data reduced following Renne and others $(13,15)$. All data reported at $2 \sigma$ and include decay constant uncertainties. 


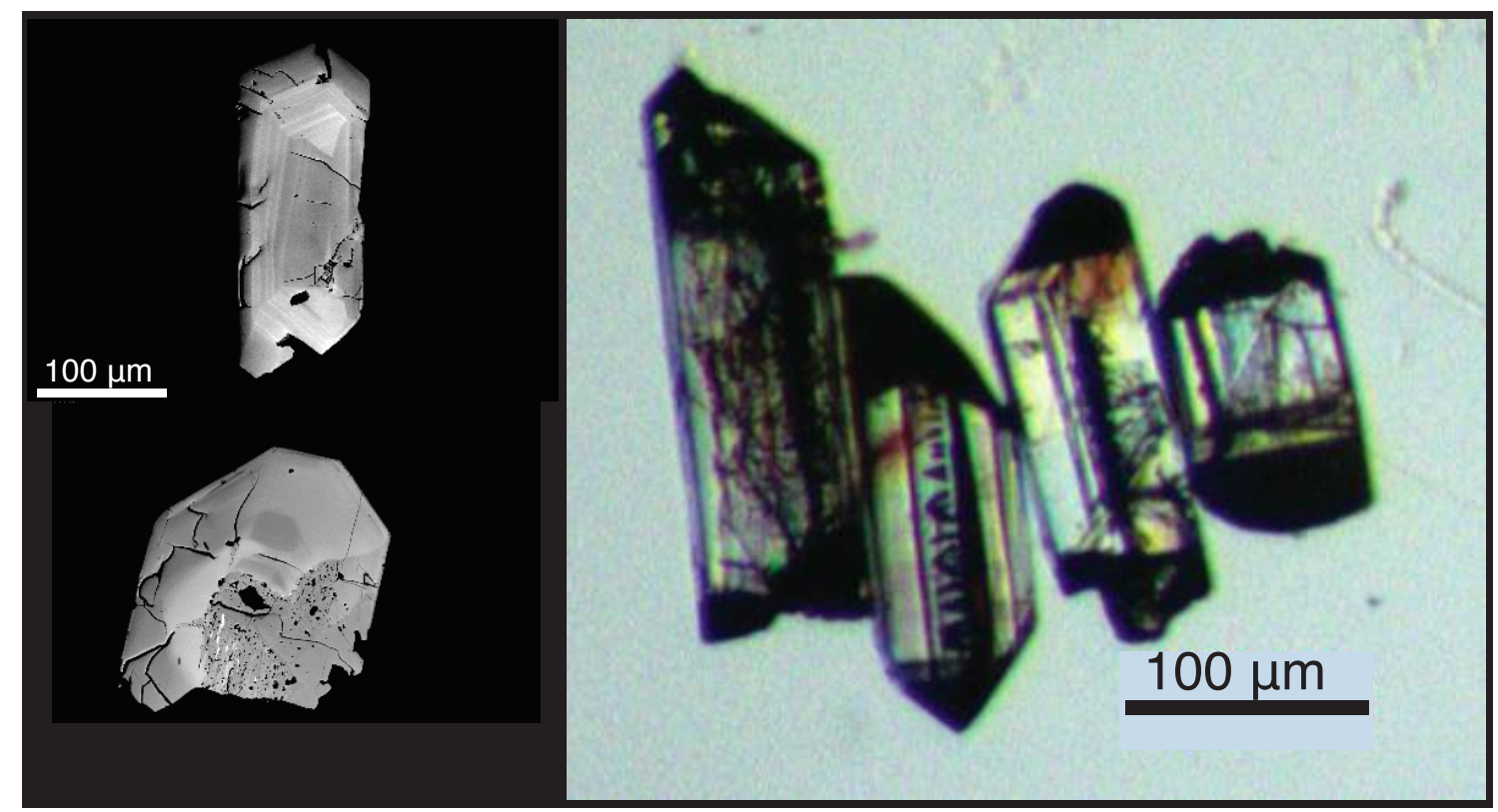

\section{Fig. S2}

Backscatter electron BSE (left) and transmitted light (right) images of zircons from the Palisades sill (left) and North Mountain Basalt (right). BSE images reveal inclusion rich zones with an inferred relatively simple single stage crystallization history (i.e. no zircon cores, embayment or reabsorption). Transmitted light images highlight the characteristics of nearly all "basaltic zircons" dated in this study; block aspect ratio, (often)unterminated, slightly metamict, with an unidentified center inclusion/alteration of melt inclusion or baddeleyite. 


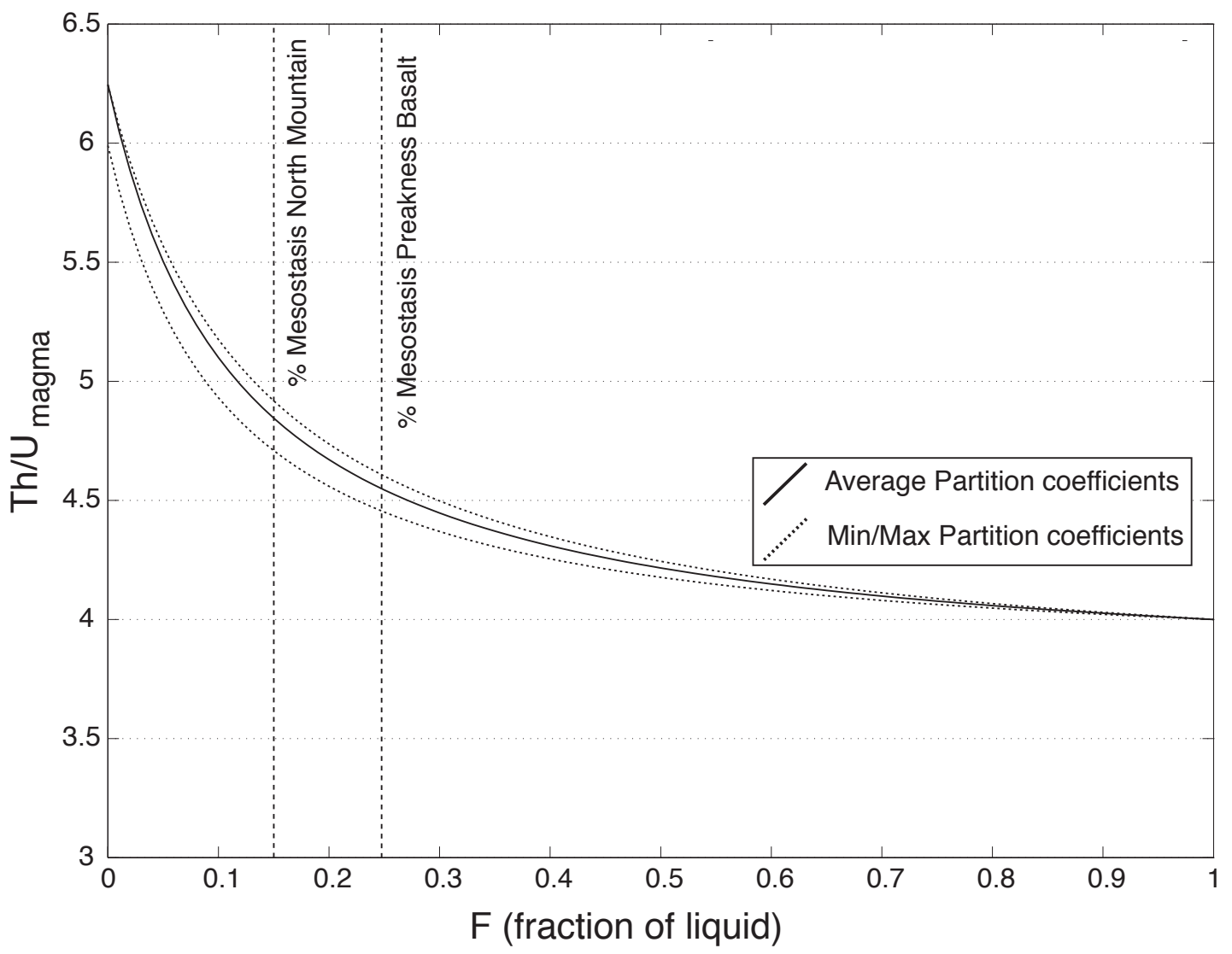

Fig. S3

Model results for the evolution of Th/U within CAMP magmas. Petrologic descriptions and modal abundances provide a probable crystallization sequence for CAMP magmas. Combined with partition coefficients for thorium and uranium for each mineral (Table S3) the Th/U evolution of a typical CAMP magma can be estimated. Shown are magmas with average reported initial $\mathrm{Th} / \mathrm{U}(4.0)$. Likely crystallization sequences will result in fractionation of $\mathrm{Th} / \mathrm{U}$ to higher values. Vertical dashed lines marked the modal estimates for $\%$ mesostasis or quenched interstitial magma found in the North Mountain and Preakness Basalts. As zircon crystallization likely occurred before the mesostasis was quenched, the intersection of the modeled Th/U evolution curves and the $\%$ mesostasis lines places a range of maximum $\mathrm{Th} / \mathrm{U}$ values. For this reason the initial CAMP Th/U value of 4.0 provides a minimum estimate for the composition that zircons crystallized from. 


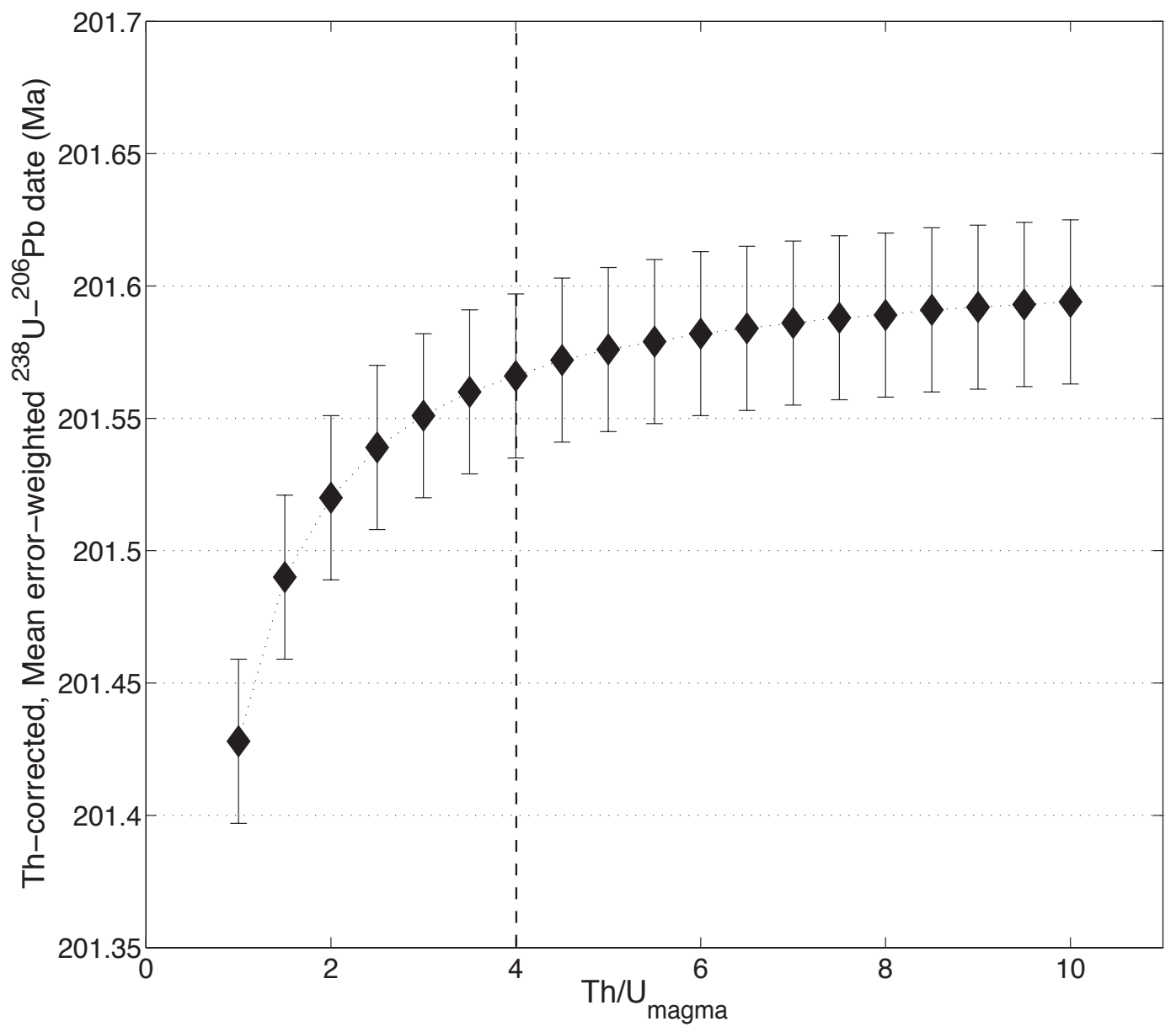

\section{Fig. S4}

Model Th-corrected ${ }^{238} \mathrm{U}-{ }^{206} \mathrm{~Pb}$ error-weighted mean dates for North Mountain basalts for a range of $\mathrm{Th} / \mathrm{U}$ magma compositions. Minimum estimate on the $\mathrm{Th} / \mathrm{U}$ of CAMP magmas of 4.0 suggests any calculated date is relatively insensitive to the possible range in the $\mathrm{Th} / \mathrm{U}$ of the magmas. This analysis applies to other dated CAMP basalts and intrusions with zircons of similar $\mathrm{Th} / \mathrm{U}$ compositions. 

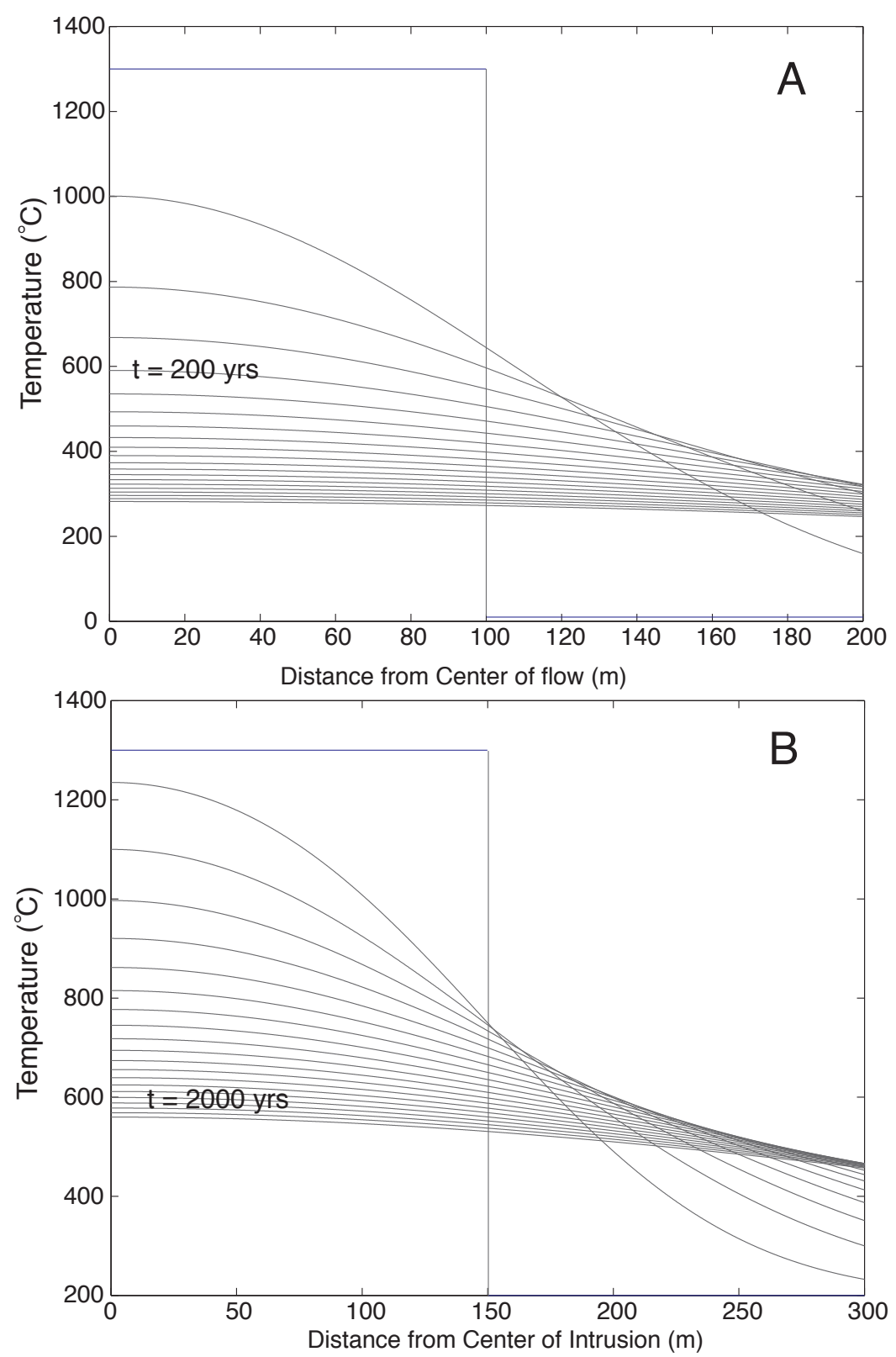

Fig. S5

Results of thermal conduction model for basaltic flows (A) and sills (B) intended to evaluate the potential time-scale of zircon residence. Basaltic flows cool sub-aerially, while the sill boundary condition is set to $200{ }^{\circ} \mathrm{C}$, temperature consistent a higher rift geotherm. Petrologic and geochemical evidence suggests that zircon crystallized within the basalt as it cooled and underwent fractional crystallization. Model conditions are intended to place a maximum estimate on the cooling time-scales for a sub-aerially cooling (a) and shallow intrusion (b). The temperature range in which zircon is likely to crystallize is $>600{ }^{\circ} \mathrm{C}$ to $<1300$. 


\begin{tabular}{|c|c|c|c|c|c|c|c|c|}
\hline & \multicolumn{4}{|c|}{ Model Inputs: } & \multicolumn{4}{|c|}{ Model Outputs: } \\
\hline & $\mathrm{U}-\mathrm{Pb}$ date & $\pm 2 \sigma(\mathrm{X})$ & Astro $\Delta \mathrm{t}$ & $\pm 2 \sigma$ & $\mathrm{U}-\mathrm{Pb}$ date & $\pm 2 \sigma(X)$ & $\pm 2 \sigma(Y)$ & $\pm 2 \sigma(\mathrm{Z})$ \\
\hline Butner & 200.916 & 0.064 & 0.633 & 0.020 & 200.930 & 0.024 & 0.059 & 0.223 \\
\hline Rossville & 201.305 & 0.034 & 0.313 & 0.030 & 201.276 & 0.024 & 0.058 & 0.223 \\
\hline Preakness & 201.274 & 0.032 & 0.283 & 0.030 & 201.279 & 0.023 & 0.058 & 0.223 \\
\hline Rapidan & 201.498 & 0.033 & 0.043 & 0.020 & 201.516 & 0.020 & 0.056 & 0.223 \\
\hline York Haven & 201.509 & 0.035 & 0.043 & 0.020 & 201.519 & 0.021 & 0.056 & 0.223 \\
\hline Palisade & 201.515 & 0.033 & 0.023 & 0.020 & 201.535 & 0.020 & 0.056 & 0.223 \\
\hline Amelal & 201.564 & 0.054 & 0.013 & 0.020 & 201.553 & 0.023 & 0.057 & 0.223 \\
\hline North Mtn & 201.566 & 0.033 & 0.003 & 0.001 & 201.561 & 0.015 & 0.055 & 0.222 \\
\hline ETE & -- & -- & 0 & 0 & 201.564 & 0.015 & 0.055 & 0.222 \\
\hline
\end{tabular}

\section{Table S2}

Model inputs and outputs for least-squares optimization of $\mathrm{U}-\mathrm{Pb}$ and astrochronologic data. All dates and date differences are expressed in millions of years ago and millions of years, respectively. Model inputs include the absolute $\mathrm{U}-\mathrm{Pb}$ chronology and the relative chronology determined by astronomical tuning, expressed here as the elapsed time since the end-Triassic extinction (ETE). Model outputs incorporate both sources of information and are therefore more precise (Figure 3B). Uncertainties labeled (X) include analytical sources only, (Y) additionally include U-Pb tracer calibration uncertainties, and $(\mathrm{Z})$ include analytical, tracer, and decay constant uncertainties. These calculations use the decay constants of Jaffey and others (60) for ${ }^{238} \mathrm{U}$ and ${ }^{235} \mathrm{U}$, Holden (61)for ${ }^{232} \mathrm{Th}$, and Cheng and others (62) for ${ }^{230} \mathrm{Th}$, along with the tracer calibration ET2535 v.3.0 and ET535 v.3.0 of Condon et al. (in prep) and McLean et al. (in prep) available at www .earth-time.org. 


\begin{tabular}{l|ccccc} 
& $\begin{array}{c}\text { Puffer and Volkert 2001 } \\
\text { Modal/Gabbroid }\end{array}$ & Modal/Pegmatoid & \multicolumn{1}{c}{ Mineral-Element partition coeficients } \\
& 35.6 & 34.1 & $0.05+/-0.03$ & $0.07+/-0.05$ & $1-5$ \\
\hline \hline Plagioclase & 31.6 & $0.01+/-0.02$ & $0.01+/-0.02$ & $1,2,6-15$ \\
Pyroxene & 34.4 & 8.3 & 0.1 & 0.1 & quenced magma does not fractionate Th/U \\
Fe-Ti oxide & 8.1 & 25.4 & - & - & 16 \\
Mesostatis & 21.5 & $0.004^{*}$ & 17.1 & 1.8 & 4 \\
Apatite & $0.004^{*}$ & &
\end{tabular}

"Maximum estimate from reported $\mathrm{P}_{2} \mathrm{O}_{5}$ concentrations

References: 1: Villemant et al., 1981; 2: McKenzie \& O'Nions 1991; 3: Bindeman \& Davis, 2000; 4: Lemarchand et al., 1987;

5: Dostal et al., 1983; 6: Latourrette \& Burnett 1992; 7: Beattie, 1993; 8: Matsui et al., 1977; 9: Hauri et al., 1994;

10: Benjamin et al., 1978; 11 Zack \& Brumm, 1998;12: Onuma et al., 1968; 13:Klemme \& Bundy 2002; 14: Wood \& Trigila 2001;

15: Adam \& Green 2006; 16: Luhr et al., 1984

\section{Table S3}

Summary of Modal abundances and distribution coefficients used to model the $\mathrm{Th} / \mathrm{U}$ evolution of CAMP magmas. 


\section{References and Notes}

1. V. E. Courtillot, P. R. Renne, On the ages of flood basalt events. C. R. Geosci. 335, 113 (2003). doi:10.1016/S1631-0713(03)00006-3

2. P. E. Olsen et al., in Catastrophic Events and Mass Extinctions: Impacts and Beyond, C. Koeberl, K. G. MacLeod, Eds. (Geological Society of America Special Paper, Boulder, CO, 2002), vol. 356, pp. 505-522.

3. M. J. Benton, Diversification and extinction in the history of life. Science 268, 52 (1995). doi:10.1126/science.7701342 Medline

4. N. Morton, Details of voting on proposed GSSP and ASSP for the base of the Hettangian Stage and Jurassic System. Int Subcomm Jurassic Stratigr Newslett 35, 74 (2008).

5. A. Marzoli et al., Extensive 200-million-year-old continental flood basalts of the Central Atlantic Magmatic Province. Science 284, 616 (1999). doi:10.1126/science.284.5414.616 Medline

6. B. Schoene, J. Guex, A. Bartolini, U. Schaltegger, T. J. Blackburn, Correlating the endTriassic mass extinction and flood basalt volcanism at the 100 ka level. Geology 38, 387 (2010). doi:10.1130/G30683.1

7. G. McHone, Volatile Emissions from Central Atlantic Magmatic Province Basalts: Mass Assumptions and Environmental Consequences (American Geophysical Union, Washington, DC, 2003), vol. 136, p. 14.

8. P. E. Olsen, D. V. Kent, M. Et-Touhami, J. H. Puffer, in The Central Atlantic Magmatic Province: Insights from Fragments of Pangea, W. E. Hames, G. McHone, P. R. Renne, C. Ruppel, Eds. (Geophysical Monograph Series, 2003), vol. 136, pp. 7-32.

9. J. H. Whiteside, P. E. Olsen, D. V. Kent, S. J. Fowell, M. Et-Touhami, Synchrony between the Central Atlantic magmatic province and the Triassic-Jurassic mass-extinction event? Palaeogeogr. Palaeoclimatol. Palaeoecol. 244, 345 (2007). doi:10.1016/j.palaeo.2006.06.035

10. F. Jourdan et al., ${ }^{40} \mathrm{Ar} /{ }^{39} \mathrm{Ar}$ ages of CAMP in North America: Implications for the TriassicJurassic boundary and the ${ }^{40} \mathrm{~K}$ decay constant bias. Lithos 110, 167 (2009). doi:10.1016/j.lithos.2008.12.011

11. A. Marzoli et al., Synchrony of the Central Atlantic magmatic province and the TriassicJurassic boundary climatic and biotic crisis. Geology 32, 973 (2004). doi:10.1130/G20652.1

12. J. C. McElwain, D. J. Beerling, F. I. Woodward, Fossil plants and global warming at the Triassic-Jurassic boundary. Science 285, 1386 (1999). doi:10.1126/science.285.5432.1386 Medline

13. M. F. Schaller, J. D. Wright, D. V. Kent, Atmospheric $\mathrm{PCO}_{2}$ perturbations associated with the Central Atlantic Magmatic Province. Science 331, 1404 (2011). doi:10.1126/science.1199011 Medline

14. B. Hönisch et al., The geological record of ocean acidification. Science 335, 1058 (2012). doi:10.1126/science.1208277 Medline 
15. S. E. Greene, D. J. Bottjer, F. A. Corsetti, W. M. Berelson, J.-P. Zonneveld, A subseafloor carbonate factory across the Triassic-Jurassic transition. Geology 40, 1043 (2012). doi:10.1130/G33205.1

16. A. Robock, Volcanic eruptions and climate. Rev. Geophys. 38, 191 (2000). doi:10.1029/1998RG000054

17. D. Gottfried, L. P. Greenland, E. Y. Campbell, Variation of Nb-Ta, Zr-Hf, Th-U and K-Cs in two diabase-granophyre suites. Geochim. Cosmochim. Acta 32, 925 (1968). doi:10.1016/0016-7037(68)90059-8

18. Materials and methods are available as supplementary materials on Science Online.

19. J. H. Puffer, K. A. Block, J. C. Steiner, Transmission of flood basalts through a shallow crustal sill and the correlation of sill layers with extrusive flows: The Palisades intrusive system and the basalts of the Newark Basin, New Jersey, U.S.A. J. Geol. 117, 139 (2009). doi:10.1086/595663

20. H. El Hachimi, Ph.D, Thesis, University of Cadi Ayyad (2012).

21. D. Gottfried, A. Froelich, J. N. Grossman, “Geochemical data for Jurassic diabase associated with early Mesozoic basins in the Eastern United States; Gettysburg Basin and vicinity, Pennsylvania and Maryland" Open-File Report 91-322-E (USGS 1991).

22. D. Gottfried, A. Froelich, J. N. Grossman, "Geochemical data for Jurassic diabase associated with early Mesozoic basins in the Eastern United States; Culpeper Basin and vicinity, Virginia and Maryland" Open-File Report 91-322-F (USGS 1991).

23. D. Gottfried, A. Froelich, J. N. Grossman, "Geochemical data for Jurassic diabase associated with early Mesozoic basins in the Eastern United States; western Newark Basin, Pennsylvania and New Jersey" Open-File Report 91-322-C (USGS, 1991).

24. R. P. Tollo, D. Gottfried, Petrochemistry of Jurassic basalt from eight cores, Newark Basin, New Jersey. Spec. Pap. Geol. Soc. Am. ••, 233 (1992).

25. M. H. L. Deenen et al., A new chronology for the end-Triassic mass extinction. Earth Planet. Sci. Lett. 291, 113 (2010). doi:10.1016/j.eps1.2010.01.003

26. L. A. Hinnov, J. G. Ogg, in Stratigraphy (2007), vol. 4, pp. 239-251.

27. F. B. VanHouten, Cyclic sedimentation and the origin of analcime-rich Upper Triassic Lockatong Formation, west-central New Jersey and adjacent Pennsylvania. Am. J. Sci. 260, 561 (1962). doi:10.2475/ajs.260.8.561

28. P. E. Olsen, D. V. Kent, Milankovitch climate forcing in the tropics of Pangaea during the Late Triassic. Palaeogeogr. Palaeoclimatol. Palaeoecol. 122, 1 (1996). doi:10.1016/0031-0182(95)00171-9

29. A. Berger, M. Loutre, J. Laskar, Stability of the astronomical frequencies over the earth's history for paleoclimate studies. Science 255, 560 (1992).

doi:10.1126/science.255.5044.560

30. J. N. Grossmann, D. Gottfried, A. J. Froelich, "Geochemical data for Jurassic Diabase associated with Early Mesozoic Basins in the Eastern United States" 91-322_J (USGS, 1991). 
31. S. Cirilli et al., Latest Triassic onset of the Central Atlantic Magmatic Province (CAMP) volcanism in the Fundy Basin (Nova Scotia): New stratigraphic constraints. Earth Planet. Sci. Lett. 286, 514 (2009). doi:10.1016/j.epsl.2009.07.021

32. D. V. Kent, P. E. Olsen, Astronomically tuned geomagnetic polarity timescale for the Late Triassic. J. Geophys. Res. 104, (B6), 12831 (1999). doi:10.1029/1999JB900076

33. M. H. L. Deenen, W. Krijgsman, M. Ruhl, J.-C. Mareschal, The quest for chron E23r at Partridge Island, Bay of Fundy, Canada: CAMP emplacement postdates the end-Triassic extinction event at the North American craton. Can. J. Earth Sci. 48, 1282 (2011). doi:10.1139/e11-015

34. M. R. Rampino, K. Caldeira, Comment on "Atmospheric $\mathrm{PCO}_{2}$ perturbations associated with the Central Atlantic Magmatic Province". Science 334, 594, author reply 594 (2011). doi:10.1126/science.1208653 Medline

35. S. P. Hesselbo, S. A. Robinson, F. Surlyk, S. Piasecki, Terrestrial and marine extinction at the Triassic-Jurassic boundary synchronized with major carbon-cycle perturbation: A link to initiation of massive volcanism? Geology 30, 251 (2002). doi:10.1130/00917613(2002)030<0251:TAMEAT $>2.0 . \mathrm{CO} ; 2$

36. J. H. Whiteside, P. E. Olsen, T. Eglinton, M. E. Brookfield, R. N. Sambrotto, Compoundspecific carbon isotopes from Earth's largest flood basalt eruptions directly linked to the end-Triassic mass extinction. Proc. Natl. Acad. Sci. U.S.A. 107, 6721 (2010). doi:10.1073/pnas.1001706107 Medline

37. M. Ruhl, N. R. Bonis, G.-J. Reichart, J. S. Sinninghe Damsté, W. M. Kürschner, Atmospheric carbon injection linked to end-Triassic mass extinction. Science 333, 430 (2011). doi:10.1126/science.1204255 Medline

38. A. Bartolini et al., Disentangling the Hettangian carbon isotope record: Implications for the aftermath of the end-Triassic mass extinction. Geochem. Geophys. Geosyst. 13, Q01007 (2012). doi:10.1029/2011GC003807

39. A. von Hillebrandt, L. Krystyn, On the oldest Jurassic ammonites of Europe (Northern Calcareous Alps, Austria) and their global significance. Geologie und Palontologie 253, 163 (2009).

40. D. V. Kent, L. Tauxe, Corrected Late Triassic latitudes for continents adjacent to the North Atlantic. Science 307, 240 (2005). doi:10.1126/science.1105826 Medline

41. J. M. Mattinson, Zircon U-Pb chemical abrastion ("CA-TIMS") method: combined annealing and multi-step partial dissolution analysis for improved precision and accuracy of zircon ages. Chem. Geol. 220, 47 (2005). doi:10.1016/j.chemgeo.2005.03.011

42. J. Hiess, D. J. Condon, N. McLean, S. R. Noble, ${ }^{238} U /{ }^{235} U$ Systematics in terrestrial uraniumbearing minerals. Science 335, 1610 (2012). doi:10.1126/science.1215507 Medline

43. J. F. Bowring, N. M. McLean, S. A. Bowring, Engineering cyber infrastructure for U-Pb geochronology: Tripoli and U-Pb_Redux. Geochem. Geophys. Geosyst. 12, Q0AA19 (2011). 
44. N. M. McLean, J. F. Bowring, S. A. Bowring, An algorithm for U-Pb isotope dilution data reduction and uncertainty propagation. Geochem. Geophys. Geosyst. 12, Q0AA18 (2011).

45. J. H. Puffer, D. L. Horter, Origin of pegmatitic segregation veins within flood basalts. Geol. Soc. Am. Bull. 105, 738 (1993). doi:10.1130/00167606(1993)105<0738:OOPSVW $>2.3 . \mathrm{CO} ; 2$

46. A. R. Philpotts, M. Carroll, J. M. Hill, Crystal-mush compaction and the origin of pegmatitic segregation sheets in a thick flood-basalt flow in the Mesozoic Hartford Basin, Connecticut. J. Petrol. 37, 811 (1996). doi:10.1093/petrology/37.4.811

47. F. Jourdan, J. P. Matzel, P. R. Renne, ${ }^{39} \mathrm{Ar}$ and ${ }^{37} \mathrm{Ar}$ recoil loss during neutron irradiation of sanidine and plagioclase. Geochim. Cosmochim. Acta 71, 2791 (2007). doi:10.1016/j.gca.2007.03.017

48. D. E. Seidemann, The hydrothermal addition of excess ${ }^{40} \mathrm{Ar}$ at the lava flows from the early Jurassic in the Hartford Basin (Northeastern U.S.A.): Implications for the time scale. Chem. Geol. Isot. Geosci. Sect. 72, 37 (1988). doi:10.1016/0168-9622(88)90035-8

49. S. Kelley, Excess argon in K-Ar and Ar-Ar geochronology. Chem. Geol. 188, 1 (2002). doi:10.1016/S0009-2541(02)00064-5

50. P. R. Renne, R. Mundil, G. Balco, K. Min, K. R. Ludwig, Joint determination of ${ }^{40} \mathrm{~K}$ decay constants and ${ }^{40} \mathrm{Ar} * /{ }^{40} \mathrm{~K}$ for the Fish Canyon sanidine standard, and improved accuracy for ${ }^{40} \mathrm{Ar} /{ }^{39} \mathrm{Ar}$ geochronology. Geochim. Cosmochim. Acta 74, 5349 (2010). doi:10.1016/j.gca.2010.06.017

51. K. F. Kuiper et al., Synchronizing rock clocks of Earth history. Science 320, 500 (2008). doi:10.1126/science.1154339 Medline

52. P. R. Renne, G. Balco, K. R. Ludwig, R. Mundil, K. Min, Response to the comment by W.H. Schwarz et al. on "Joint determination of ${ }^{40} \mathrm{~K}$ decay constants and ${ }^{40} \mathrm{Ar} * /{ }^{40} \mathrm{~K}$ for the Fish Canyon sanidine standard, and improved accuracy for ${ }^{40} \mathrm{Ar} /{ }^{39} \mathrm{Ar}$ geochronology" by P.R. Renne et al. (2010). Geochim. Cosmochim. Acta 75, 5097 (2011). doi:10.1016/j.gca.2011.06.021

53. K. Min, R. Mundil, P. R. Renne, K. R. Ludwig, A test for systematic errors in ${ }^{40} \mathrm{Ar} /{ }^{39} \mathrm{Ar}$ geochronology through comparison with $\mathrm{U} / \mathrm{Pb}$ analysis of a 1.1-Ga rhyolite. Geochim. Cosmochim. Acta 64, 73 (2000). doi:10.1016/S0016-7037(99)00204-5

54. G. R. Dunning, J. P. Hodych, U/Pb zircon and baddeleyite ages for the Palisades and Gettysburg sills of the northeastern United States: Implications for the age of the Triassic/Jurassic boundary. Geology 18, 795 (1990). doi:10.1130/00917613(1990)018<0795:UPZABA >2.3.CO;2

55. J. P. Hodych, G. R. Dunning, Did the Manicouagan impact trigger end-of-Triassic mass extinction? Geology 20, 51 (1992). doi:10.1130/00917613(1992)020<0051:DTMITE $>2.3 . \mathrm{CO} ; 2$

56. B. Schoene, J. L. Crowley, D. J. Condon, M. D. Schmitz, S. A. Bowring, Reassessing the uranium decay constants for geochronology using ID-TIMS U-Pb data. Geochim. Cosmochim. Acta 70, 426 (2006). doi:10.1016/j.gca.2005.09.007 
57. N. M. Ratcliffe, in Studies of the Early Mesozoic Basins of the EUnited States, A. J. Froelich, G. R. Robinson Jr., Eds. (U.S. Geol. Surv. Bull., 1988), vol. 1776, pp. 113-140.

58. K. S. Heier, J. J. W. Rogers, Radiometric determination of thorium, uranium and potassium in basalts and in two magmatic differentiation series. Geochim. Cosmochim. Acta 27, 137 (1963). doi:10.1016/0016-7037(63)90055-3

59. H. Bertrand, J. Dostal, C. Dupuy, Geochemistry of early mesozoic tholeiites from Morocco. Earth Planet. Sci. Lett. 58, 225 (1982). doi:10.1016/0012-821X(82)90196-0

60. J. Dostal, M. Durning, Geochemical constraints on the origin and evolution of early Mesozoic dikes in Atlantic Canada. Eur. J. Mineral. 10, 79 (1998).

61. J. M. Cebria, J. Lopez-Ruiz, M. Doblas, L. T. Martins, J. Munha, Geochemistry of the Early Jurassic Messejana, Plasencia dyke (Portugal, Spain); implications on the origin of the Central Atlantic Magmatic Province. J. Petrol. 44, 547 (2003). doi:10.1093/petrology/44.3.547

62. D. Gottfried, A. Froelich, J., J. N. Grossman, "Geochemical data for Jurassic diabase associated with early Mesozoic basins in the Eastern United States; eastern Newark Basin, New York and New Jersey" Open-File Report 91-322-C (USGS, 1991).

63. J. H. Puffer, R. A. Volkert, Pegmatoid and gabbroid layers in Jurassic Preakness and Hook Mountain Basalts, Newark Basin, New Jersey. J. Geol. 109, 585 (2001). doi: $10.1086 / 321958$

64. D. J. Kontak, On the edge of CAMP: Geology and volcanology of the Jurassic North Mountain Basalt, Nova Scotia. Lithos 101, 74 (2008). doi:10.1016/j.lithos.2007.07.013

65. Y. Matsui, N. Onuma, H. Nagasawa, H. Higuchi, S. Banno, Crystal structure control in trace element partition between crystal and magma. Tectonics 100, 315 (1977).

66. N. Onuma, H. Higuchi, H. Wakita, H. Nagasawa, Trace element partition between two pyroxenes and the host lava. Earth Planet. Sci. Lett. 5, 47 (1968). doi:10.1016/S0012$\underline{821 X(68) 80010-X}$

67. T. M. Benjamin, W. R. Heuser, D. S. Burnett, in Proceedings of the Lunar and Planetary Science Conference, R. B. Merrill, Ed. (Pergamon, 1978), vol. 1, pp. 393-1406.

68. B. Villemant, H. Jaffrezic, J.-L. Joron, M. Treuil, Distribution coefficients of major and trace elements; fractional crystallization in the alkali basalt series of Chaine des Puys (Massif Central, France). Geochim. Cosmochim. Acta 45, 1997 (1981). doi:10.1016/0016$\underline{7037(81) 90055-7}$

69. J. Dostal, C. Dupuy, J. P. Carron, M. Le Guen de Kerneizon, R. C. Maury, Partition coefficients of trace elements: Application to volcanic rocks of St. Vincent, West Indies. Geochim. Cosmochim. Acta 47, 525 (1983). doi:10.1016/0016-7037(83)90275-2

70. J. F. Luhr, I. S. E. Carmichael, J. C. Varekamp, The 1982 eruptions of El Chichon Volcano, Chiapas, Mexico: Mineralogy and petrology of the anhydritebearing pumices. $J$. Volcanol. Geotherm. Res. 23, 69 (1984). doi:10.1016/0377-0273(84)90057-X

71. F. Lemarchand, B. Villemant, G. Calas, Trace element distribution coefficients in alkaline series. Geochim. Cosmochim. Acta 51, 1071 (1987). doi:10.1016/0016-7037(87)90201-8 
72. D. McKenzie, R. K. O'Nions, Partial melt distributions from inversion of rare earth element concentrations. J. Petrol. 32, 1021 (1991). doi:10.1093/petrology/32.5.1021

73. T. Z. LaTourrette, D. S. Burnett, Experimental determination of $U$ and Th partitioning between clinopyroxene and natural and synthetic basaltic liquid. Earth Planet. Sci. Lett. 110, 227 (1992). doi:10.1016/0012-821X(92)90050-6

74. P. Beattie, The generation of uranium series disequilibria by partial melting of spinel peridotite: constraints from partitioning studies. Earth Planet. Sci. Lett. 117, 379 (1993). doi:10.1016/0012-821X(93)90091-M

75. E. H. Hauri, T. P. Wagner, T. L. Grove, Experimental and natural partitioning of Th, U, Pb and other trace elements between garnet, clinopyroxene and basaltic melts. Chem. Geol. 117, 149 (1994). doi:10.1016/0009-2541(94)90126-0

76. T. Zack, R. Brumm, in 7th International Kimberlite Conference, J. J. Gurney, J. L. Gurney, M. D. Pascoe, S. H. Richardson, Eds. (Cape Town, South Africa, 1998), pp. 986-988.

77. I. N. Bindeman, A. M. Davis, Trace element partitioning between plagioclase and melt: investigation of dopant influence on partition behavior. Geochim. Cosmochim. Acta 64, 2863 (2000). doi:10.1016/S0016-7037(00)00389-6

78. B. J. Wood, R. Trigila, Experimental determination of aluminous clinopyroxene melt partition coefficients for potassic liquids, with application to the evolution of the Roman province potassic magmas. Chem. Geol. 172, 213 (2001). doi:10.1016/S0009$\underline{2541(00) 00259-X}$

79. S. Klemme, J. D. Blundy, B. J. Wood, Experimental constraints on major and trace element partitioning during partial melting of eclogite. Geochim. Cosmochim. Acta 66, 3109 (2002). doi:10.1016/S0016-7037(02)00859-1

80. J. Adam, T. Green, Trace element partitioning between mica- and amphibole-bearing garnet lherzolite and hydrous basanitic melt: 1. Experimental results and the investigation of controls on partitioning behaviour. Contrib. Mineral. Petrol. 152, 1 (2006). doi:10.1007/s00410-006-0085-4

81. J. H. Puffer, D. L. Horter, Origin of pegmatitic segregation veins within flood basalts. Geol. Soc. Am. Bull. 105, 738 (1993). doi:10.1130/00167606(1993)105<0738:OOPSVW>2.3.CO;2

82. J. W. Valley, A. J. Cavosie, B. Fu, W. H. Peck, S. A. Wilde, Comment on "Heterogeneous Hadean hafnium: Evidence of continental crust at 4.4 to 4.5 Ga”. Science 312, 1139 , author reply 1139 (2006). doi:10.1126/science.1125301 Medline

83. J. D. Greenough, J. Dostal, Cooling history and differentiation of a thick North Mountain Basalt flow (Nova Scotia, Canada). Bull. Volcanol. 55, 63 (1992). doi:10.1007/BF00301120

84. S. Nomade et al., Chronology of the Central Atlantic Magmatic Province: Implications for the Central Atlantic rifting processes and the Triassic-Jurassic biotic crisis. Palaeogeogr. Palaeoclimatol. Palaeoecol. 244, 326 (2007). doi:10.1016/j.palaeo.2006.06.034

85. W. E. Hames, P. R. Renne, C. Ruppel, New evidence for geologically instantaneous emplacement of earliest Jurassic Central Atlantic magmatic province basalts on the North 
American margin. Geology 28, 859 (2000). doi:10.1130/0091-

7613(2000)28<859:NEFGIE $>2.0 . \mathrm{CO} ; 2$

86. E. K. Beutel, S. Nomade, A. K. Fronabarger, P. R. Renne, Pangea's complex breakup: A new rapidly changing stress field model. Earth Planet. Sci. Lett. 236, 471 (2005). doi:10.1016/j.epsl.2005.03.021

87. A. Marzoli et al., Timing and duration of the Central Atlantic magmatic province in the Newark and Culpeper basins, eastern U.S.A. Lithos 122, 175 (2011). doi:10.1016/j.lithos.2010.12.013

88. K. B. Knight et al., The Central Atlantic Magmatic Province at the Triassic-Jurassic boundary: Paleomagnetic and ${ }^{40} \mathrm{Ar} /{ }^{39} \mathrm{Ar}$ evidence from Morocco for brief, episodic volcanism. Earth Planet. Sci. Lett. 228, 143 (2004). doi:10.1016/j.epsl.2004.09.022

89. P. Rossi, A. Cocherie, C. M. Fanning, Y. Ternet, U-Pb zircon SHRIMP dating of Pyrenean tholeiitic dolerites (ophites): evidence for an age encompassing the Trias-Jurassic limit and relationships with earliest North Pyrenean Infraliassic tuffs. C. R. Geosci. 335, 1071 (2003). doi:10.1016/j.crte.2003.09.011

90. A. H. Jaffey, K. F. Flynn, L. E. Glendenin, W. C. Bentley, A. M. Essling, Precision measurement of half-lives and specific activities of ${ }^{235} \mathrm{U}$ and ${ }^{238} \mathrm{U}$. Phys. Rev. C Nucl. Phys. 4, 1889 (1971). doi:10.1103/PhysRevC.4.1889

91. N. E. Holden, Total half-lives for selected nuclides. Pure Appl. Chem. 62, 941 (1990). doi:10.1351/pac199062050941

92. H. Cheng et al., The half-lives of uranium-234 and thorium-230. Chem. Geol. 169, 17 (2000). doi:10.1016/S0009-2541(99)00157-6 
Table S1 (.xls file)

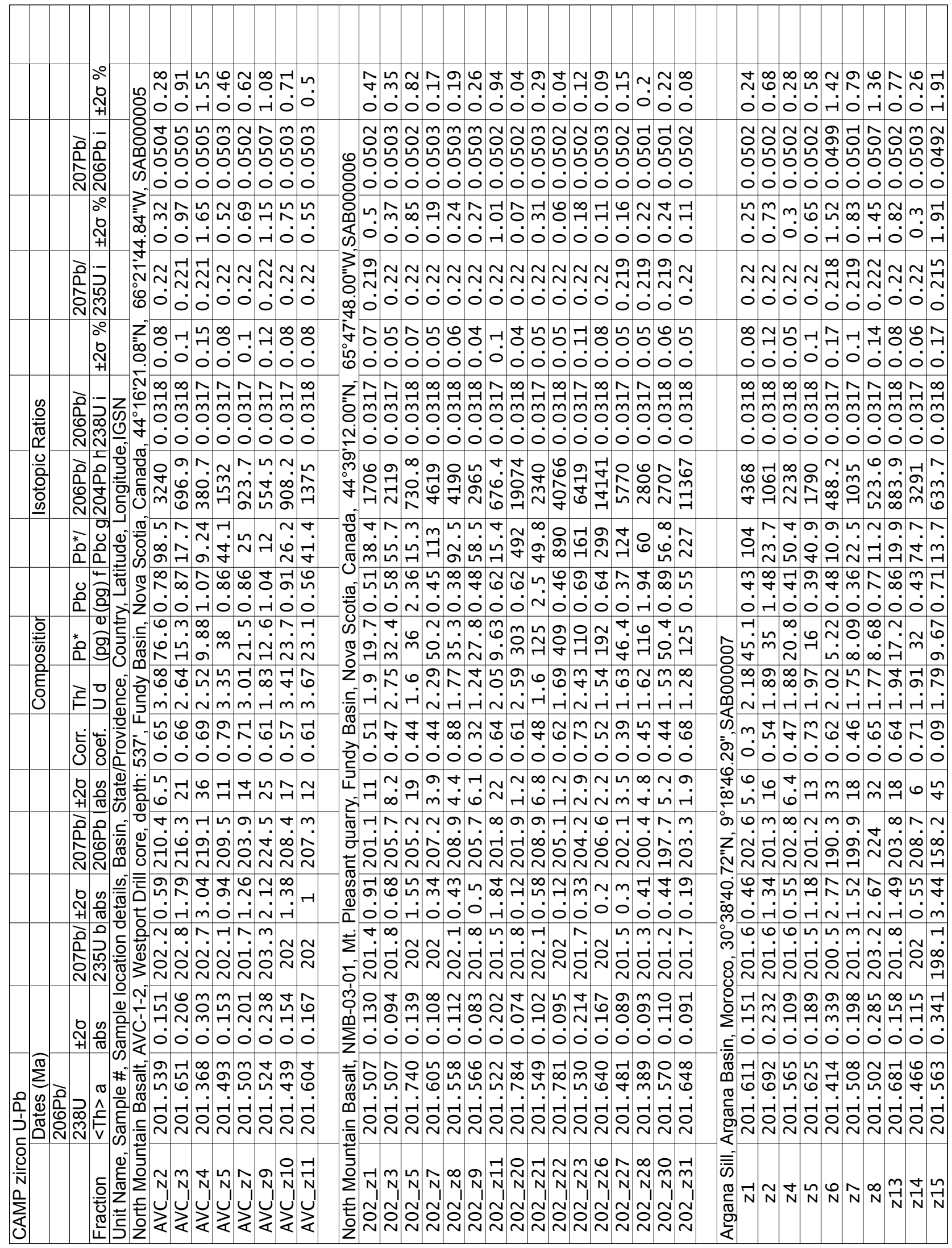




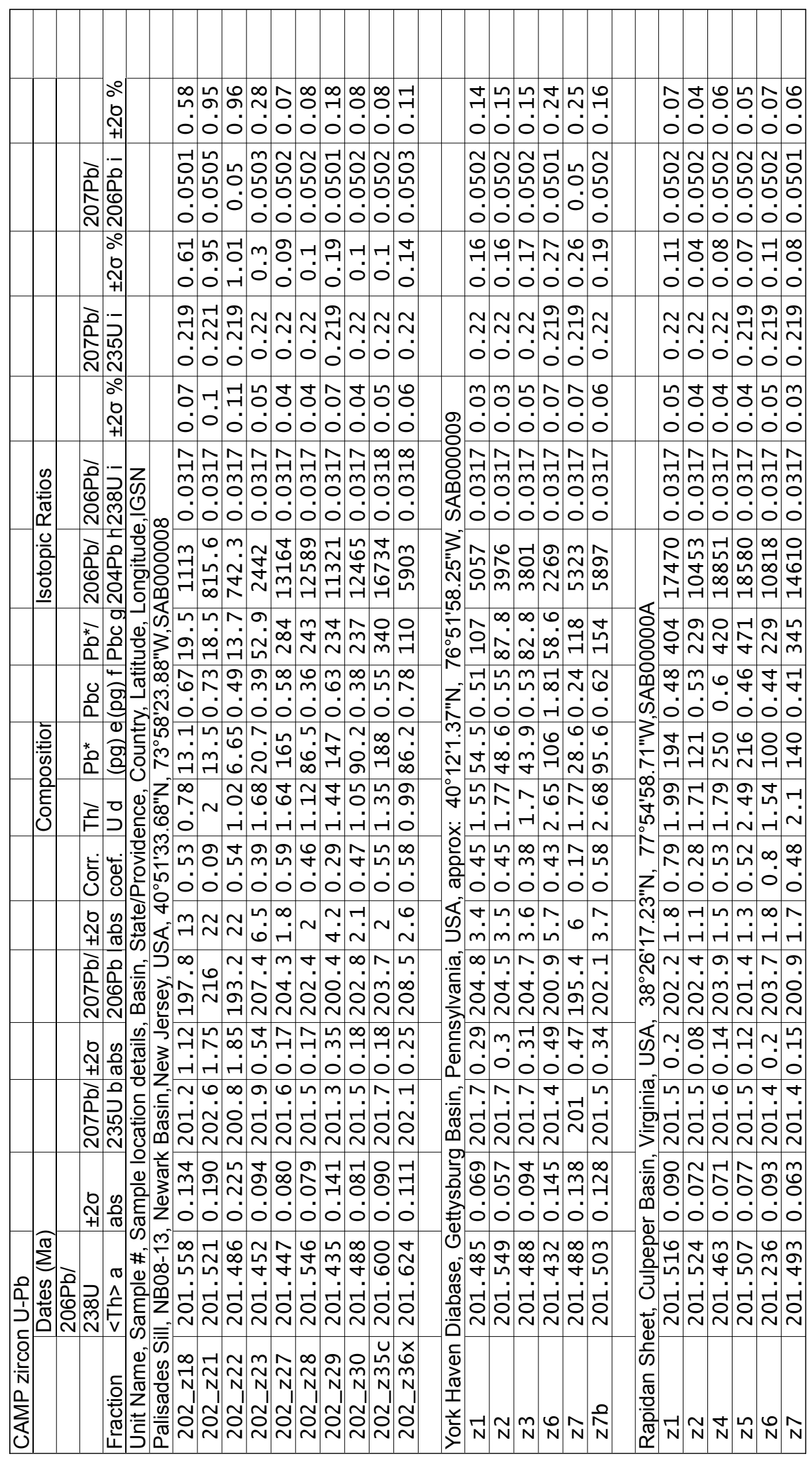




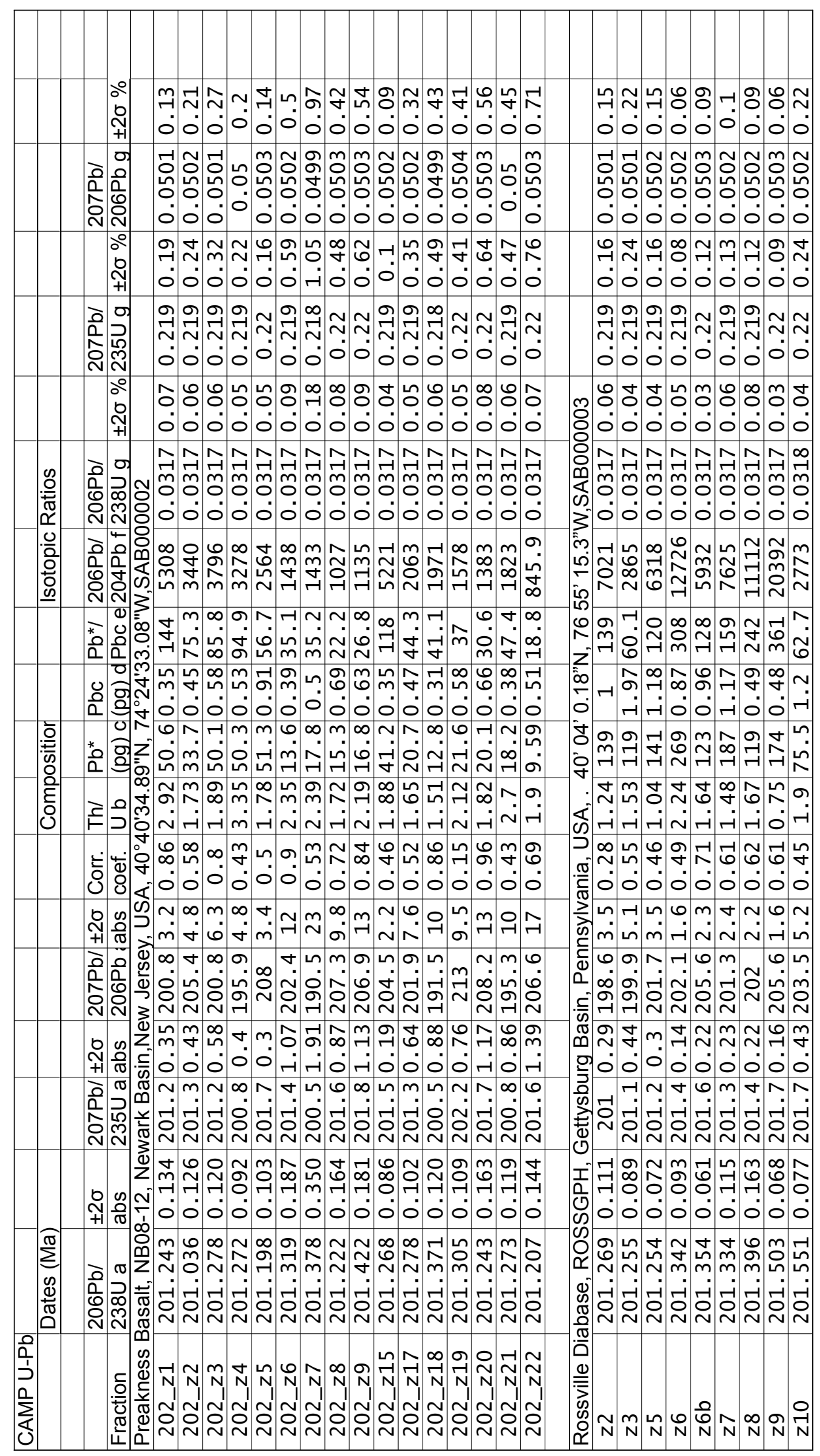




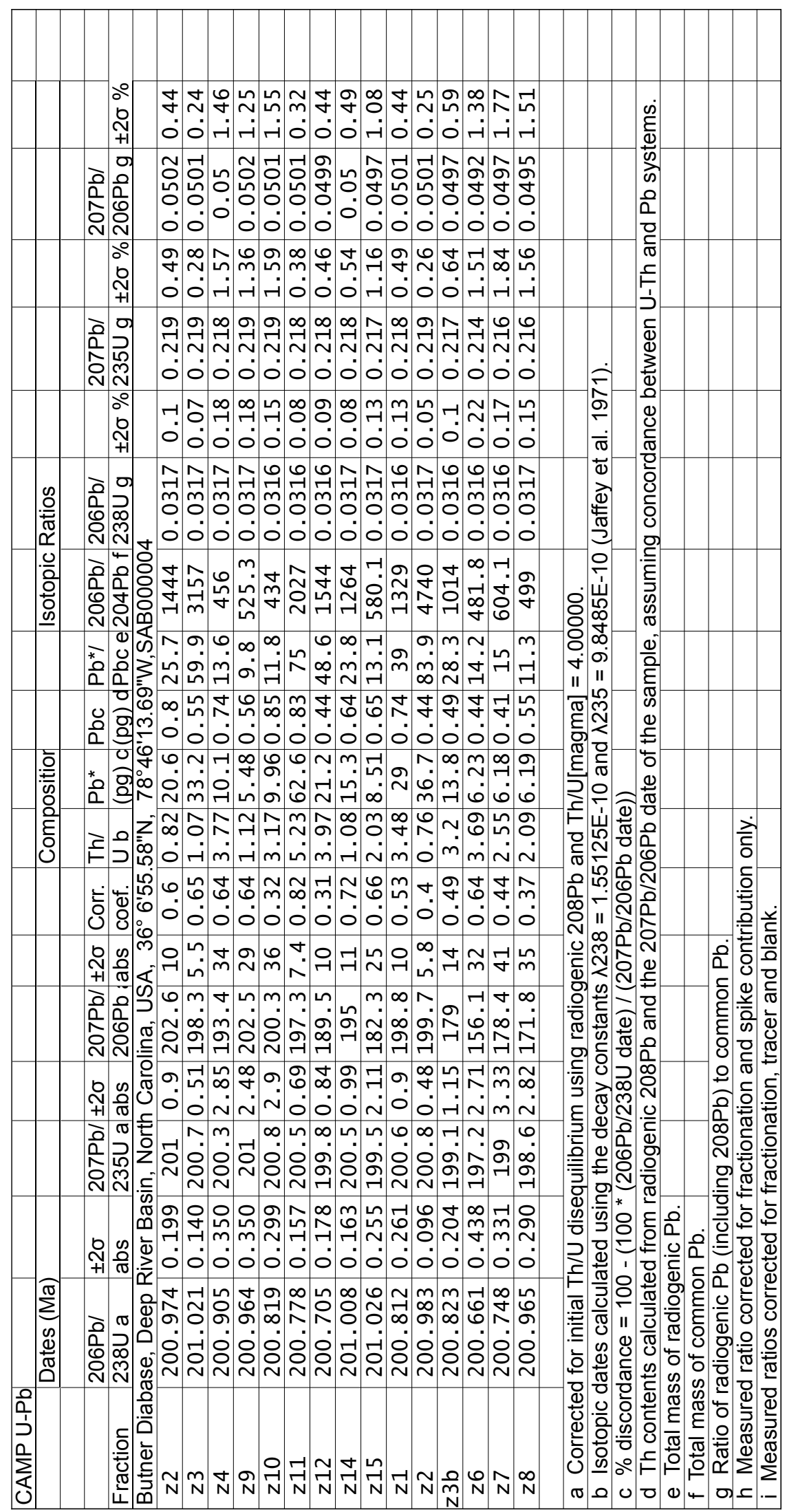

